\title{
Arctic Sea Ice and Eurasian Climate: A Review
}

\author{
GAO Yongqi ${ }^{1,2}$, SUN Jianqi* ${ }^{* 1}$, LI Fei ${ }^{1}$, HE Shengping ${ }^{1,5}$, Stein SANDVEN ${ }^{2}$, YAN Qing ${ }^{1}$, \\ ZHANG Zhongshi $^{1,3}$, Katja LOHMANN ${ }^{6}$, Noel KEENLYSIDE ${ }^{4,2}$, Tore FUREVIK ${ }^{4}$, and SUO Lingling ${ }^{2}$ \\ ${ }^{1}$ Nansen-Zhu International Research Centre, Institute of Atmospheric Physics, Chinese Academy of Sciences, Beijing 100029 \\ ${ }^{2}$ Nansen Environmental and Remote Sensing Center/Bjerknes Center for Climate Research, Bergen 5006, Norway \\ ${ }^{3}$ Uni Research/Bjerknes Center for Climate Research, Bergen 5007, Norway \\ ${ }^{4}$ Geophysical Institute, University of Bergen/Bjerknes Center for Climate Research, Bergen 5007, Norway \\ ${ }^{5}$ Climate Change Research Center, Chinese Academy of Sciences, Beijing 100029 \\ ${ }^{6}$ Max-Planck Institute for Meteorology, Hamburg 20146, Germany
}

(Received 11 August 2014; revised 15 September 2014; accepted 16 September 2014)

\begin{abstract}
The Arctic plays a fundamental role in the climate system and has shown significant climate change in recent decades, including the Arctic warming and decline of Arctic sea-ice extent and thickness. In contrast to the Arctic warming and reduction of Arctic sea ice, Europe, East Asia and North America have experienced anomalously cold conditions, with record snowfall during recent years. In this paper, we review current understanding of the sea-ice impacts on the Eurasian climate. Paleo, observational and modelling studies are covered to summarize several major themes, including: the variability of Arctic sea ice and its controls; the likely causes and apparent impacts of the Arctic sea-ice decline during the satellite era, as well as past and projected future impacts and trends; the links and feedback mechanisms between the Arctic sea ice and the Arctic Oscillation/North Atlantic Oscillation, the recent Eurasian cooling, winter atmospheric circulation, summer precipitation in East Asia, spring snowfall over Eurasia, East Asian winter monsoon, and midlatitude extreme weather; and the remote climate response (e.g., atmospheric circulation, air temperature) to changes in Arctic sea ice. We conclude with a brief summary and suggestions for future research.
\end{abstract}

Key words: Arctic sea ice, Eurasian climate, Arctic Oscillation, review

Citation: Gao, Y. Q., and Coauthors, 2015: Arctic sea ice and Eurasian climate: A review. Adv. Atmos. Sci., 32(1), 92-114, doi: 10.1007/s00376-014-0009-6.

\section{Introduction}

Global warming is enhanced at high latitudes where the Arctic surface air temperature has risen twice as large as the global average in recent decades - a feature called Arctic amplification. Although the Arctic warming implies a melting of sea-ice cover (e.g., Johannessen and Bjørgo, 1995; Johannessen, 2008; Johannessen et al., 2004), its dynamicthermodynamic response is neither straightforward nor necessarily linear (Zhang et al., 2000). This is also true for the response of the atmosphere to sea-ice reductions (Magnusdottir et al., 2004; Deser et al., 2004; Deser and Teng, 2008). Sea ice plays an important role in the climate system due to its reflection of solar radiation back to the atmosphere and its blocking of the direct exchange of energy and mass between the atmosphere and the ocean. In addition, the melting and formation of sea ice can influence the surface sea water density and therefore potentially change the ocean circulation.

\footnotetext{
* Corresponding author: SUN Jianqi

Email: sunjq@mail.iap.ac.cn
}

Satellite observations (1979 to present) indicate that Arctic sea ice cover has declined over recent decades, and that the rate of decline is increasing (e.g., Comiso et al., 2008). Arctic sea ice cover reached a record low in September 2012. Analyses indicate that the recent Arctic warming signal is consistent with the reduction in sea ice cover (Screen and Simmonds, 2010).

The reduction in Arctic sea ice cover could potentially impact upon the climate in the Northern Hemisphere $(\mathrm{NH})$ (Ma et al., 2012; Zhou and Wang, 2014). The impact of Arctic sea ice on global climate has been reviewed by Budikova (2009). The links between Arctic sea ice, storms and the North Atlantic Oscillation (NAO) have been reviewed by Bader et al. (2011). Recently, Vihma (2014) reviewed the influence of Arctic sea-ice reduction on climate and weather. Considering new studies on the link between Arctic sea ice and the Eurasian climate in recent years, the purpose of this paper is to summarize the available literature with a special focus on the impact of Arctic sea ice on the Eurasian climate and the related uncertainty. We also cover paleoclimate studies on the impact of sea ice. 
The remainder of the paper is organized as follows: Section 2 briefly summarizes the past, present and future status of the Arctic sea ice. Section 3 summarizes atmospheric and oceanic forcings on the Arctic sea ice. Section 4 summarizes the impact of Arctic sea ice on the paleoclimate, present climate, and projected climate, including both observational and modelling studies. The related uncertainty is discussed in section 5 , followed by a summary and future perspective in section 6 .

\section{Arctic sea ice change: Past, present and fu- ture}

Paleo-proxy reconstructions suggest that winter Arctic sea ice appeared approximately $47 \mathrm{Ma}$ (million years ago) with the global cooling in the Cenozoic $(\sim 65 \mathrm{Ma})$. There was year-round sea-ice cover in at least part of the Arctic beginning 14-13 Ma, and widespread Arctic sea-ice cover present during the last 2-3 million years. Arctic sea-ice cover shows clear oscillations during the glacial-interglacial cycles. The last low-ice event related to orbital forcing (high insolation) was in the early Holocene (Polyak et al., 2010; Stein et al., 2012).

Historical records and high-resolution paleo-proxy reconstructions have been used to investigate the multidecadal variation of Arctic sea ice. For example, Miles et al. (2014) synthesized available historical records of Arctic sea-ice over the past several centuries in the Atlantic sector and found strong co-variability between Arctic sea ice and the Atlantic Multidecadal Oscillation (AMO), suggesting an intrinsic link between the AMO and Arctic sea ice. This was also suggested by early modelling studies (e.g., Jungclaus et al., 2005; Mahajan et al., 2011). Kinnard et al. (2011) also proposed that meridional ocean heat transport to the Arctic could possibly be the key driver for the multidecadal variations in Arctic seaice cover.

Since October 1978, the satellite-observed Arctic seaice extent shows downward trends in all months, with the largest downward trend appearing in September of each year (Stroeve et al., 2012a; Cassano et al., 2013) and two record minima having occurred in 2007 and 2012 (Francis, 2013). For example, using the mean of 1981-2010 as a base period, the declining trend in sea-ice extent is $-0.40 \times 10^{6}$ $\mathrm{km}^{2}(10 \mathrm{yr})^{-1}$ [or 3\% $(10 \mathrm{yr})^{-1}$ ] in March and $-0.89 \times$ $10^{6} \mathrm{~km}^{2}(10 \mathrm{yr})^{-1}$ [or $12 \%(10 \mathrm{yr})^{-1}$ ] in September from 1979 to 2013 (Miles et al., 2014). The observed reduction in sea-ice extent is significantly faster than that simulated by most numerical models using realistic anthropogenic increases in greenhouse gases (Stroeve et al., 2012b). The projections from the models in the Fifth Assessment Report (AR5) of the Intergovernmental Panel on Climate Change (IPCC) show that the summer (September) Arctic sea ice could nearly disappear (sea ice extent less than $1 \times 10^{6}$ $\mathrm{km}^{2}$ for at least 5 consecutive years) by the middle of the 21st century under a high-emissions scenario (IPCC, 2013; Overland and Wang, 2013).

\section{Arctic sea ice: Atmospheric or oceanic forc- ing?}

Numerous studies have investigated the causes of Arctic sea-ice variations and trends. Simmonds and Keay (2009) suggest that low Arctic sea-ice extent conditions in September provide additional energy for cyclonic systems, which could further exert greater mechanical forcing to move more sea ice into warmer waters and result, in turn, in less sea-ice extent. The wintertime sea-ice cover variability shows a seesaw pattern between the Labrador Sea and the GreenlandBarents Seas (Gerdes, 2006), which is driven by the NAO through wind forcing, oceanic heat transport, and surface heat exchanges (Frankignoul et al., 2014). Koenigk et al. (2009) suggest that negative-phase NAO leads to anomalous high pressure over Novaya Zemlya and anomalous low pressure over Svalbard, strengthening the winds across the northern border of the Barents Sea, and thus the sea-ice transport into the Barents Sea increases. Ding et al. (2014) found that the annual mean tropical SSTs during 1979-2012 could have stimulated anomalous Rossby wave-train activity that extended from the central tropical Pacific towards the Arctic region, leading to a negative trend in the NAO. The negative trend of the NAO has been strongly associated with the surface and tropospheric warming in northeastern Canada and Greenland since 1979, which could potentially have impacted on the variation of the Arctic sea ice. Matsumura et al. (2014) revealed that earlier spring snowmelt over Eurasia causes a warmer land surface and therefore amplified stationary Rossby waves, leading to a deceleration of the subpolar jet. As a result, an anomalous anticyclone emerges over the Arctic Ocean. The intensified surface anticyclonic circulation played a contributing role in accelerating the sea-ice decline during 1988-2011, via transpolar drift and export out of the Arctic Ocean through the Fram Strait.

In particular, numerous studies have investigated the causes of the remarkable low Arctic sea-ice extent in 2007. It is agreed that a primary driver for the rapid sea-ice cover decrease in 2007 was the summer Arctic Dipole (anomalous high sea-level pressure over the Beaufort Sea and anomalous low pressure over the Siberian Arctic), which has persisted through to June of 2012, thus creating an intensified meridional flow across the Arctic (Overland et al., 2012). This mechanism was revealed by Stroeve et al. (2008), who suggested that the promotion of persistent southerly wind anomalies in the Laptev and East Siberian seas favors strong melt and ice transport away from the coast. L'Heureux et al. (2008) suggest that the anomalous anticyclone associated with an anomalously strong positive phase of the PacificNorth American pattern contributes to a precipitous decrease in Arctic sea ice through increasing solar radiation, enhancing the poleward transport of warm air, and increasing sea-ice drift away from the western Arctic.

However, atmospheric forcing seems to become less effective in the recovery of Arctic sea ice. For example, the extreme negative phase of the Arctic Oscillation (AO) in winter 2009/2010 should have favored the retention of Arctic 
sea ice through the 2010 summer melt season. However, the sea-ice extent ended up as the third lowest since satellite records began (Stroeve et al., 2011b). Consequently, the potential impact of ocean forcing needs to be fully understood. Jackson et al. (2010) indicated that the stronger nearsurface stratification from increasing ice melt stores the heat in the near surface (20-25 m depth), which can then be used to melt ice and reduce ice thickness. Comiso et al. (2008) revealed that the increased absorption of solar radiation induced by the increasing open water area in the Arctic basin is likely the primary cause for recent Arctic sea-ice reduction. Besides, the extensive open water in recent Septembers has led to an increasingly thin, first-year ice in the following spring that is vulnerable to melting out in the summer (Stroeve et al., 2012a). Additionally, the Arctic winter seaice retreat has been related to the warmer Pacific waters flowing in to the Arctic through the Bering Strait, which may act as a trigger for the onset of solar-driven melt (Woodgate et al., 2010). The increase of the Atlantic inflow to the western Barents Sea and the increased delivery of oceanic heat to the ice-sheet margin also contribute to the Arctic winter sea-ice reduction (Stroeve et al., 2012a). The decreasing of summer snowfall over the Arctic Ocean and Canadian Archipelago results in loss of snow-on-ice, leading to a substantial decrease in the surface albedo over the Arctic Ocean. Accordingly, the solar input to the Arctic Ocean is increased, causing additional surface ice melt (Screen and Simmonds, 2012). Langehaug et al. (2013) investigated the Fram Strait sea-ice area export in CMIP5 (Coupled Model Intercomparison Project Phase 5) models, and found that the simulated southward export of sea ice in the Fram Strait constitutes a major fraction of Arctic sea-ice reduction in five models (sea-ice area export in Fram Strait can be diagnosed in six CMIP5 models) over 1957 to 2005 . They found low but significant correlations on interannual timescales between the Fram Strait seaice export, both in terms of area and volume, and the Arctic Basin sea-ice thickness. All six models (NorESM1-M; CNRM-CM5; MPI-ESM-LR; MRI-CGCM3; ACCESS1-3; MPI-ESM-P) show that an increase in ice-area export leads to a decrease in sea-ice thickness. Sandø et al. (2014) diagnosed the historical simulation (1850 to 2005) performed by the Norwegian Earth System Model (NorESM) and found that the ocean has stronger direct impacts on changes in sea-ice mass in terms of freezing and melting than the atmosphere, both in the mean and with respect to variability over 1950 to 2005. Day et al. (2012) used model and satellite data to suggest that the AMO warming phase could explain $5 \%-30 \%$ of the satellite era (1979-2010) summer seaice reduction and an even higher proportion for the winter sea ice. Recently, Wyatt and Curry (2014) suggested that the North Atlantic Ocean halocline, which is generated because the sea ice in the Eurasian Arctic is exposed to the open ocean, is mostly responsible for wintertime sea-ice cover. This is because the halocline is resulting vertical density structure and prevents ocean heat at depth from reaching the surface. So, where a strong halocline exists, sea-ice growth is promoted.

\section{Arctic sea ice and Eurasian climate}

\subsection{Paleo studies}

Due to the uncertainties in sea-ice reconstruction in the past climate, it remains difficult to investigate the impact of sea ice on the paleoclimate. A few modeling studies have shown that sea-ice cover likely played an important role in the paleoclimate.

The mid-Pliocene $(\sim 3 \mathrm{Ma})$ is thought to be an analogy of future climate owing to the high $\mathrm{CO}_{2}$ concentration $(\sim 405$ ppmv) with reduced ice sheets and northward expansion of boreal forest (e.g., Dowsett et al., 2010; Yan et al., 2014). Multiple proxy data show that the mid-Pliocene Arctic was likely warmer than today (Salzmann et al., 2013). During the mid-Pliocene period, the reduced sea-ice cover contributed significantly to the surface warming at mid- and high latitudes in the NH. For example, based on energy balance calculations from eight mid-Pliocene coupled-model simulations, Hill et al. (2014) point out that the albedo feedbacks, particularly those of sea ice and ice sheets, could have provided the most significant enhancements to high-latitude warming during the mid-Pliocene. Using an atmospheric general circulation model (AGCM) [version 3 of the Community Atmosphere Model (CAM3)], Ballantyne et al. (2013) show that with perennial ice-free conditions across the Arctic, the simulated annual mean surface temperatures over the $\mathrm{NH}$ agree better with terrestrial reconstructions during the midPliocene. They further attribute this result to the removal of Arctic sea ice, leading to loss of latent heat from the ocean to the atmosphere and contributing to the warming of continental interiors including the Eurasian continent.

During the Quaternary (about 2.6 Ma), sea ice feedbacks likely played an important role in glacial-interglacial cycles. Although it is often believed that shifts in glacial-interglacial cycles were controlled by Earth's orbital changes, Gildor and Tziperman (2000) suggested that sea ice, via its albedo and insulating effects, could have caused a rapid switch of the climate system from a growing to a retreating ice-sheet phase, and hence regulated global climate. Using a coupled atmosphere-slab ocean model, Vavrus (1999) investigated the climate effect of ice motion under orbital boundary conditions at $6 \mathrm{kyr} \mathrm{BP}$ (paleoclimate warmer than present) and $115 \mathrm{kyr}$ BP (paleoclimate colder than present). He found that the atmosphere over central Arctic $\left(80^{\circ}-90^{\circ} \mathrm{N}\right)$ was warmed (cooled) up by $0.7^{\circ} \mathrm{C}\left(2.0^{\circ} \mathrm{C}\right)$ at $6 \mathrm{kyr} \mathrm{BP}(115 \mathrm{kyr} \mathrm{BP})$ in the experiment with sea-ice dynamics compared to the experiment without sea-ice dynamics, indicating the important role of sea-ice motion to regional temperature changes. By conducting a set of sensitivity experiments with varied albedo and thickness of sea ice, Gildor et al. (2013) investigated the albedo and insulating effects of sea ice in the hydrological cycle, with a focus on rain- and snowfall over the major ice sheets during Last Glacial Maximum. They found a warmer climate and an increase in snowfall over the ice sheets as a result of reduced sea-ice cover. The insulating effect of the sea ice on the hydrological cycle was found to be larger than the albedo effect. 
During the past 2000 years, the expanded Arctic sea ice may have been crucial to sustaining the cold climate during the Little Ice Age (LIA; ca. 1400-1700 AD). Miller et al. (2012) suggest that strong volcanic eruptions produced abrupt summer cooling at these times, allowing Arctic sea ice to expand. The increased sea-ice export may then have engaged a self-sustaining sea-ice/ocean feedback mechanism in the northern North Atlantic that maintained suppressed summer air temperatures over the North Atlantic-Arctic land $\left(>60^{\circ} \mathrm{N}\right.$ and $90^{\circ} \mathrm{W}$ to $30^{\circ} \mathrm{E}$ ) for centuries after volcanic aerosols were removed from the atmosphere. Lehner et al. (2013) also indicated that an increase in the Nordic Sea seaice extent on decadal timescales during the LIA as a consequence of major volcanic eruptions led to a spin-up of the subpolar gyre and a weakened Atlantic meridional overturning circulation, eventually causing a persistent, basin-wide cooling.

To summarize, paleoclimate studies suggest that the Arctic sea ice was a key player for the surface warming in mid and high latitudes in the NH during different paleo periods, and that the Arctic sea ice has the potential to shift glacialinterglacial cycles.

\subsection{Observation studies}

Observation-based studies suggest that the change in Arctic sea ice is linked to change in the Eurasian climate. Most studies focus on the impact of reduced autumn and winter Arctic sea ice on the Eurasian climate in winter.

Observation-based studies in the early 20th century, as briefly summarized by Herman and Johnson (1978), suggest: a potential link between the winter conditions in Europe and the ice conditions in East Greenland during the previous summer (Hildebrandsson, 1914); a correlation between the Arctic sea-ice margin and air temperatures and pressures over Europe (Schell, 1956, 1970). In addition, Tao (1959) summarized the weather forecast in China from 1949 to 1958 and noticed that almost all extreme cold spells (drops in air temperature of more than $10^{\circ} \mathrm{C}$ within 24 hours) in East Asia were originated from the Barents Sea or the Kara Sea with different pathways. Also apparent was an adjustment in the planetary waves over the Eurasian continent when the extreme cold spells took place in China. More recent studies (Liu et al., 2007; Li and Wang, 2013b), using satellite-and reanalysis-derived Arctic sea-ice concentrations, demonstrate a close relationship between the variability of the North Pacific sea ice and the East Asian winter climate. Their analyses indicated that, associated with negative sea-ice anomalies in the Sea of Okhotsk and positive ones in the Bering Sea, the East Asian jet stream and East Asian trough are weaker than normal, leading to warm and wet conditions in northeast China and central Siberia. When the winter sea ice displays uniform negative anomalies throughout the North Pacific, the East Asian winter monsoon (EAWM) is stronger, which leads to cold and dry conditions along the east coast of Asia (Wang and He, 2012, 2013; He, 2013; He and Wang, 2013a; He et al., 2013; Wang et al., 2013). Based on the seaice concentration data derived from version 1 of the UK Met
Office Hadley Centre's sea ice and SST dataset (HadISST) and National Centers for Environmental Prediction-National Center for Atmospheric Research (NCEP-NCAR) reanalysis datasets, Honda et al. (2009) found that a reduction of sea-ice cover over the Barents-Kara Seas in late autumn can stimulate a stationary Rossby wave in early winter. This tends to induce an amplification of the Siberian High and results in significant cold anomalies over the Far East in early winter and zonally elongated cold anomalies from Europe to the Far East in late winter. On the basis of the sea-ice concentration obtained from the British Atmospheric Data Centre, NCEP-NCAR reanalysis and Japanese reanalysis data, Wu et al. (2011) showed that a low autumn sea-ice concentration in the eastern Arctic and Eurasian marginal seas, and thus higher SST, leads to higher surface air temperatures confined to the Barents-Kara Seas. Involving a negative feedback loop, this pattern causes positive sea level pressure (SLP) anomalies over northern Eurasia, thereby strengthening the Siberian high. Wu et al. (2013) used NCEP-NCAR reanalysis and Japanese 25-yr Reanalysis (JRA-25) winter daily (1 December-28 February) data for the period 1979-2012 to reveal that the negative phase of the tripole wind pattern corresponded to an anomalous anticyclone over northern Eurasia during winter, as well as two anomalous cyclones over southern Europe and northeastern Asia. These anomalous cyclones in turn led to enhanced winter precipitation in these two regions, as well as negative surface temperature anomalies over northern Asia. The intensity of the tripole wind pattern and the frequency of its extreme negative phase were significantly correlated with autumn Arctic sea-ice anomalies. Using the Arctic sea ice obtained from the National Snow and Ice Data Center, snow cover obtained from the Rutgers University Global Snow Lab and NCEP-NCAR reanalysis II data, Liu et al. (2012) indicated that the increase in snowfall over the United States and Eurasia in recent winters could be attributed to an increase in the frequency of blocking events caused by the recent Arctic autumn sea-ice loss. During light ice winters in the Barents Sea, Inoue et al. (2012) showed that the lower baroclinicity over the Barents Sea prevents winter cyclones over the Nordic Seas traveling eastward, and anomalous warm/cold advection then prevails over the Barents Sea/eastern Siberia due to an anticyclonic anomaly over the Siberian coast of the Barents Sea. Composite analysis of JRA-25 atmospheric reanalysis data, based on years with the five lowest $(2002,2005,2006,2007,2008)$ and five highest $(1980,1983,1986,1992,1996)$ September Arctic sea-ice extents, showed that more open water associated with less sea ice during autumn in the Arctic Ocean reduces the atmospheric stability and leads to more frequent and more intense autumn cyclones in the Atlantic sector of the Arctic (Stroeve et al., 2011a). Tang et al. (2013a) analyzed the reanalysis data from European Centre for Medium-Range Weather Forecasts (ECMWF) and Arctic sea-ice extent derived from passive microwave satellite data. They suggested that a winter highpressure anomaly prevails over the sub-arctic in association with a winter sea-ice reduction, and that this favors the occurrence of cold winter extremes at midlatitudes of the northern 
continents. Furthermore, these winter atmospheric circulation anomalies are more strongly associated with simultaneous sea-ice reduction instead of summer or autumn sea-ice changes. The cold winters in extra-polar regions are dynamically connected with the Arctic sea-ice loss through the polar stratosphere (Kim et al., 2014). On the basis of observational analyses and model experiments, Kim et al. (2014) suggested that the decreased sea-ice cover during November-December over the Barents-Kara seas could enhance the upward propagation of planetary-scale waves with wavenumbers of 1 and 2 , subsequently weakening the stratospheric polar vortex in January-February. The weakened polar vortex preferentially induced a negative phase of $\mathrm{AO}$ at the surface, resulting in low temperatures in north part of Eurasia.

However, recent studies point out that the influence of Arctic sea ice on the Eurasian climate might be unstable. Based on NCEP-NCAR reanalysis and HadISST data, Li and Wang (2012) revealed that the relationship between the variation of autumn sea-ice cover over the Kara-Laptev Seas and winter AO has been strengthened since the early 1980s, and suggested that the impact of Kara-Laptev autumn seaice cover on the northern Eurasian winter precipitation has intensified. Using the same datasets, Li and Wang (2014) later found that the co-variability between the autumn seaice cover in the region of $\left(65^{\circ}-82^{\circ} \mathrm{N}, 105^{\circ} \mathrm{E}-135^{\circ} \mathrm{W}\right)$ and the EAWM has become stronger since the early 1990s. In addition, again using the NCEP-NCAR reanalysis and HadISST dataset, Li et al. (2014) showed that the recent reduction of autumn Arctic sea-ice cover in the domain of $\left(67^{\circ}-85^{\circ} \mathrm{N}\right.$, $30^{\circ}-135^{\circ} \mathrm{E}$ ) caused the East Asian jet stream to extend westward toward East Asia after the 1980s. This led to a strengthening and southward shift of Rossby waves over East Asia, and therefore resulted in a strengthening of the AO-EAWM relationship.

Li and Wang (2013a), using NCEP-NCAR reanalysis and version 1 HadISST data, found that the rapid decline of autumn Arctic sea-ice cover could have enhanced moisture transport to Siberia and consequently contributed to the increased snow cover there during the following spring. This favored the southward invasion of cold air via strong radiative cooling and large-scale descending motion and further contributed to the spring surface cooling trend along the coast of East Asia after the late 1990s.

Changes in Arctic sea ice have also been linked to summer precipitation in Eurasia. As already summarized by Vihma (2014), early studies suggested that the extent of spring Arctic sea-ice cover is closely connected with summer precipitation in East Asia (Zhao et al., 2004; Wu et al., 2009; Guo et al., 2014), although the pathways or mechanisms differ among studies.

Also summarized by Vihma (2014), Francis and Vavrus (2012), using NCEP-NCAR reanalysis data, identified that the sea-ice loss related to Arctic warming-by reducing the meridional temperature gradient and favoring a weakened poleward gradient in 1000-500 hPa air thicknesses-could slow down the eastward progression of Rossby waves in the upper troposphere. They suggested that this slower move- ment of waves would cause associated weather patterns in the midlatitudes (e.g. drought, flooding, cold spells and heat waves) to be more persistent. By combining satellite observations of early summer snow cover and summer sea-ice extent with atmospheric reanalysis data, Tang et al. (2013b) suggested that summer extreme weather events in the midlatitudes are more frequently associated with summer seaice extent reduction, which could increase the upper-level geopotential height, weaken upper-level zonal winds at high latitudes, and lead to a general northward shift in the jet stream. The contribution of Arctic sea-ice decline to the change in 1000-500 hPa air thickness was revealed by Overland and Wang (2010). By analyzing NCEP-NCAR reanalysis data, they suggested that a reduction of summer Arctic sea-ice extent can lead to more open water in late summer; the additional heat is therefore stored in the Arctic Ocean and then released to the atmosphere during the following autumn. As a result, the surface air temperature during late autumn in the period 2002-2008 was higher than normal, contributing to an increase in the $1000-500 \mathrm{hPa}$ air thickness in October-December. They concluded that a reduction in Arctic sea ice had a direct connection to increased thickness fields in every year, but not necessarily to the SLP fields. However, the mechanism suggested by Francis and Vavrus (2012) is still under debate. Based on three reanalysis datasets [ERA-interim, NCEP1, and NASA's ModernEra Retrospective Analysis for Research and Applications (MERRA)], Barnes (2013) investigated trends in the meridional extent of atmospheric waves over North America and the North Atlantic and suggested that previously reported positive trends in Rossby waves were likely an artifact of the methodology. There was no significant and robust decrease in planetary-scale wave phase speeds and no significant increase in the frequency of blocking occurrence in any season in any of the three reanalyses over the reanalysis period (1980-2011). A recent study by Screen and Simmonds (2013) using ERA-Interim reanalysis data also provided evidence that the trends in planetary waves suggested by Francis and Vavrus (2012) may be an artifact of the methodology. They demonstrated that an alternative metric that was insensitive to a shift of Z500, did not yield significant positive trends in wave amplitude, suggesting that the wave elongation reported by Francis and Vavrus (2012) was at least partially an artifact of the poleward shift of the isopleths with polar warming.

To summarize, statistical analyses of observation-based and reanalysis data show that the reduction/change of autumn and/or winter sea ice in the Arctic marginal seas (the Barents/Kara Seas in the Atlantic sector; the Bering Sea and the Sea of Okhotsk in the Pacific sector) is linked to the winter and spring climate change (atmosphere circulation, air temperature and snowfall) in Eurasia. Changes in spring Arctic sea ice have been linked to East Asian summer rainfall. However, recent studies also suggest that the link between autumn Arctic sea ice and EAWM is unstable. More observational data are needed to test the link between the Arctic warming and extreme weather in the midlatitudes via a slowdown of 
Rossby waves.

The connection between the NAO and Arctic sea ice has drawn much more attention. The NAO presents one of the most prominent anomaly modes of intermonthly to interdecadal variability in the NH (Sun et al., 2009; Sun and Wang, 2012; Zhou et al., 2013) and is characterized by a large-scale alternation of atmospheric mass with centers of action near the Icelandic low and Azores high (e.g., Hurrell, 1995). There are indications that the atmosphere drives the ocean on seasonal to interannual timescales, whereas the ocean may force the atmosphere on multidecadal timescales (e.g., Gulev et al., 2013). Early studies also suggested that a mechanism of negative feedback exists between the Arctic sea ice and the NAO.

As reviewed by Bader et al. (2011), there are many observational-based studies that have addressed the sea-ice impact on the NAO (Yamamoto et al., 2006; Honda et al., 2009; Francis et al., 2009; Wu and Zhang, 2010). Based on satellite and reanalysis-derived sea-ice concentration data, Yamamoto et al. (2006) suggested that the dominant interannual mode of mid-winter northern hemispheric sea ice variability - a seesaw pattern in both Atlantic and Pacific sectors - tends to affect the NAO in late winter via Rossby wave trains triggered by Pacific sea-ice anomalies. Using NCEP-NCAR reanalysis and satellite-observed sea-ice concentration (SIC), it has been found that a negative-NAOlike pattern in autumn/winter is likely a response to a reduction in summer/autumn sea ice (Francis et al., 2009; Wu and Zhang, 2010). Using Granger causality and time series of weekly SIC seesaw and the NAO, which were calculated from the National Snow and Ice Data Center sea-ice concentrations and NCEP-NCAR reanalysis, Strong et al. (2009) showed that positive-phase NAO causes a seesaw pattern during winter to early spring (December-April), with positive SIC anomalies in the Labrador Sea and negative ones in the Barents Sea; the seesaw, in turn, drives an NAO with opposite phase. These results illustrate a negative feedback process: the sea-ice patterns associated with a positive polarity of the NAO tend to generate negative NAO-like atmospheric response patterns. As reviewed by Bader et al. (2011), a negative phase of the NAO during winter could also be associated with positive sea-ice concentrations in the Sea of Okhotsk (Mesquita et al., 2011). In addition, on the basis of ECMWF ERA-Interim data and monthly SIC data from the UK Met Office Hadley Centre, Jaiser et al. (2012) indicated that reduced SIC in August/September and associated Arctic warming exert a remote impact on the large-scale atmospheric circulation during winter. The amplified warming in autumn reduces the atmospheric stability and leads to an enhanced baroclinicity in autumn, which could further impact the structure of large-scale planetary waves in the following winter. This mechanism provides a possible pathway for how autumn sea-ice anomalies impact atmospheric flow patterns (i.e., NAO, AO). Jaiser et al. (2013) discussed the stratospheric response to Arctic sea-ice retreat by analyzing ECMWF ERA-Interim data and monthly SIC from the UK Met Office Hadley Centre. It was revealed that $\mathrm{Au}-$
gust/September Arctic SIC has a significant impact on tropospheric and stratospheric geopotential heights in the following winter. During August/September low-ice conditions, the upward Eliassen-Palm (EP) fluxes due to planetary waves are enhanced, leading to additional tropospheric wave energy into the stratosphere, which favors warmer stratospheric temperatures and therefore weakens the tropospheric polar vortex. Consequently, a negative tropospheric AO/NAO pattern is found. However, considering the major conclusions of the above studies have mostly been drawn from a very limited number of years (generally since 1979), Hopsch et al. (2012) suggested that reported results often cannot be considered as conclusive or robust enough for further statistical analysis. Hopsch et al. (2012) revisited the issue by comparing results for two different time periods - the satellite era (1979-2010) and a longer time series that also included the pre-satellite period (1950-2010) - and confirmed the emergence of an NAOlike pattern in the mid-troposphere geopotential height in the winter months following a decline in September SIC; however, the pathway suggested by the aforementioned studies was found to be insufficiently robust from a statistical significance perspective. They suggested that longer and more reliable datasets are needed before conclusions can be properly drawn on the impacts and feedback processes between autumn Arctic sea ice and the following winter's NAO. The interaction between the NAO and a sea-ice concentration seesaw between the Labrador Sea and the Greenland-Barents Sea has also been revealed by Frankignoul et al. (2014), by using the SIC from the National Snow and Ice Data Center and SLP anomalies obtained from the NCEP Climate Forecast System Reanalysis. The NAO drives the seesaw and in return the seesaw precedes a midwinter/spring NAO-like signal of opposite polarity but with a strengthened northern lobe, thus acting as a negative feedback, with maximum squared covariance at a lag of 6 weeks. Changes in the November sea-ice cover in the Barents Sea could lead to an additional heat source and intensified cyclones in downstream Arctic regions in the following months. This effect seems to exhibit a characteristic that is similar to the NAO/AO, without extending into the stratosphere, but it generates cold anomalies over the northern continents, potentially adding to anomalies directly induced by a negative AO (Petoukhov and Semenov, 2010; Inoue et al., 2012).

In summary, using statistical analysis techniques on different reanalysis products and sea-ice data, a mechanism of negative feedback between the AO/NAO and sea ice is suggested, albeit the pathway is insufficiently robust at present. Changes in summer/autumn/winter Arctic sea ice likely affect autumn/winter AO/NAO.

\subsection{Modeling studies}

Because changes in sea ice are also forced by changes in the atmosphere and ocean, it has been difficult to demonstrate clearly whether an atmospheric anomaly correlated with a sea-ice anomaly is the cause instead of an effect of the anomaly. Climate models are ideal tools to explore and isolate the impact of sea ice on atmosphere. Both AGCMs 
and coupled climate models (CCMs), including the regional climate models, have been used to isolate/investigate the impact of sea ice on the climate. With regard to sea-ice perturbation experiments, the numerical simulations that are performed generally fall into one of two types: those forced by observed sea-ice anomalies (Table 1) and those forced by projected anomalies (Table 2).

\subsubsection{Response to observed/realistic sea ice}

\subsubsection{Winter sea-ice impact}

Sea-ice impact in numerical simulations begin with winter sea-ice anomalies, since the air-sea temperature gradient in winter is strongest and therefore a large impact of sea ice is expected.

Herman and Johnson (1978) were among the first to investigate the impact of observed winter (January-February) sea-ice anomalies in the Arctic marginal seas on the simulated atmosphere in an AGCM. The model they used was developed at the Goddard Laboratory for Atmospheric Sciences. The sea-ice anomalies were based on observed sea ice during 1961-77 in the Atlantic sector and during 1973-77 in the Pacific sector. The simulated winter climate response showed the zonal mean air temperature below $800 \mathrm{hPa}$ to be $2^{\circ} \mathrm{C}$ lower between $50^{\circ} \mathrm{N}$ and $70^{\circ} \mathrm{N}$ with sea-ice expansion in marginal seas. In particular, they found a cooling signal at $700 \mathrm{hPa}$ over northwest Russia. Yang et al. (1994) were among the first to explore Arctic sea-ice impact on the East Asian summer monsoon (EASM) using an AGCM, and the model they used was developed at the Australian Numerical Meteorology Research Centre (ANMRC). They found the EASM to be strengthened in response to more sea-ice cover in the Greenland Sea and Barents Sea. Honda et al. (1996) used an AGCM developed at the Meteorological Research Institute with a horizontal resolution of $5.6^{\circ} \times 5.6^{\circ}$ to investigate the impact of observed winter heavy/light seaice cover in the Sea of Okhotsk. They found that the response between the heavy and light ice cases showed significant differences not only around the Sea of Okhotsk, but also downstream in the troposphere, which was a stationary Rossby wave response to an anomalous surface heat flux in the Sea of Okhotsk. Wu et al. (1999), using an AGCM developed at the Institute of Atmospheric Physics, suggested that winter heavy sea-ice conditions in the Barents-Kara Seas is associated with a weakened EAWM and cold air inactivity in China by exciting the Eurasian teleconnection. Magnusdottir et al. (2004) and Deser et al. (2004), forcing version 3 of the NCAR's Community Climate Model (CCM3) with a realistic spatial pattern of sea-ice cover following the observed trend during 1958-97, found that a reduction in wintertime (December-March) sea-ice extent in the North Atlantic and Arctic Ocean could result in more zonally oriented storm tracks, corresponding to a negative-phase NAO response. They also suggested that, in a sense, the extent of sea ice and its concentration might play a different but important role in determining the atmospheric response. Deser et al. (2007), using CCM3 and identical sea-ice (a positive NAO-driven sea-ice anomaly pattern) and SST forcings to those in Magnusdottir et al. (2004) and Deser et al. (2004), diagnosed the transient response of wintertime atmospheric circulation to wintertime sea-ice anomalies in the North Atlantic sector, and found the surface heat-flux anomalies induced by the prescribed sea-ice anomalies to be the driving force behind the initial atmospheric response, and that the response becomes gradually more barotropic and larger in both spatial extent and magnitude. In particular, the initial adjustment of the atmospheric circulation begins with a localized baroclinic response, which is characterized by an out-of-phase relationship between geopotential height anomalies in the lower and upper troposphere, and reaches maximum amplitude in 510 days and persists for 2-3 weeks. As the ice-forcing continues, the response becomes progressively more barotropic. In 2-2.5 months, the atmosphere reaches equilibrium stage, characterized by an equivalent barotropic structure that resembles the negative polarity of the NAO, and this pattern is maintained primarily by nonlinear transient eddy fluxes of vorticity related in part to changes in tropospheric Rossby wave breaking.

Alexander et al. (2004), forcing CCM3 with the maximum (in 1982/83) and minimum (in 1995/96) wintertime (November-March) Arctic sea-ice cover, investigated the influence of Arctic sea-ice anomalies during winter on the atmospheric circulation. It was found that the Arctic sea-ice anomalies give rise to surface heat-flux anomalies in relatively small spatial extents but with very large amplitude. Furthermore, they also found that the interactions between ice and atmosphere in the North Atlantic (North Pacific) sector dampen (enhance) the original atmospheric circulation, showing a negative (positive) feedback on the atmosphere of wintertime sea ice in the North Atlantic (North Pacific). However, the large-scale response is distinctly different in the Pacific, where ice-extent anomalies in the Sea of Okhotsk generate a wave train that extends downstream over North America, but the wave train response is greatly diminished when the model is driven by ice concentration rather than ice-extent anomalies. Singarayer et al. (2006) forced the Hadley Centre Atmospheric Model (HadAM3) with climatological SSTs and observed SIC from 1980 to 2000, with the aim to investigate the direct climate impacts of decreasing Arctic sea ice. The simulated surface air temperature (SAT) response to ice forcing most closely matched the observed SAT variability over the 1993-96 period, which saw the largest interannual variation in ice area, indicating sea-ice forcing to be an important factor (note that their simulation used climatological SSTs) in shaping the surface air temperature (SAT) anomalies. Model studies (Magnusdottir et al., 2004; Alexander et al., 2004; Gerdes, 2006) have suggested that North Atlantic sea-ice anomalies influence the NAO/AO, which has a great impact on East Asian January temperatures (He and Wang, 2013b), while North Pacific sea ice primarily influences the atmospheric circulation through the generation of stationary Rossby wave trains (Honda et al., 1999). By implying improved and more realistic sea-ice and snowalbedo feedbacks in the ECHO-GCCM, Dethloff et al. (2006) investigated the feedbacks between regional Arctic climate 


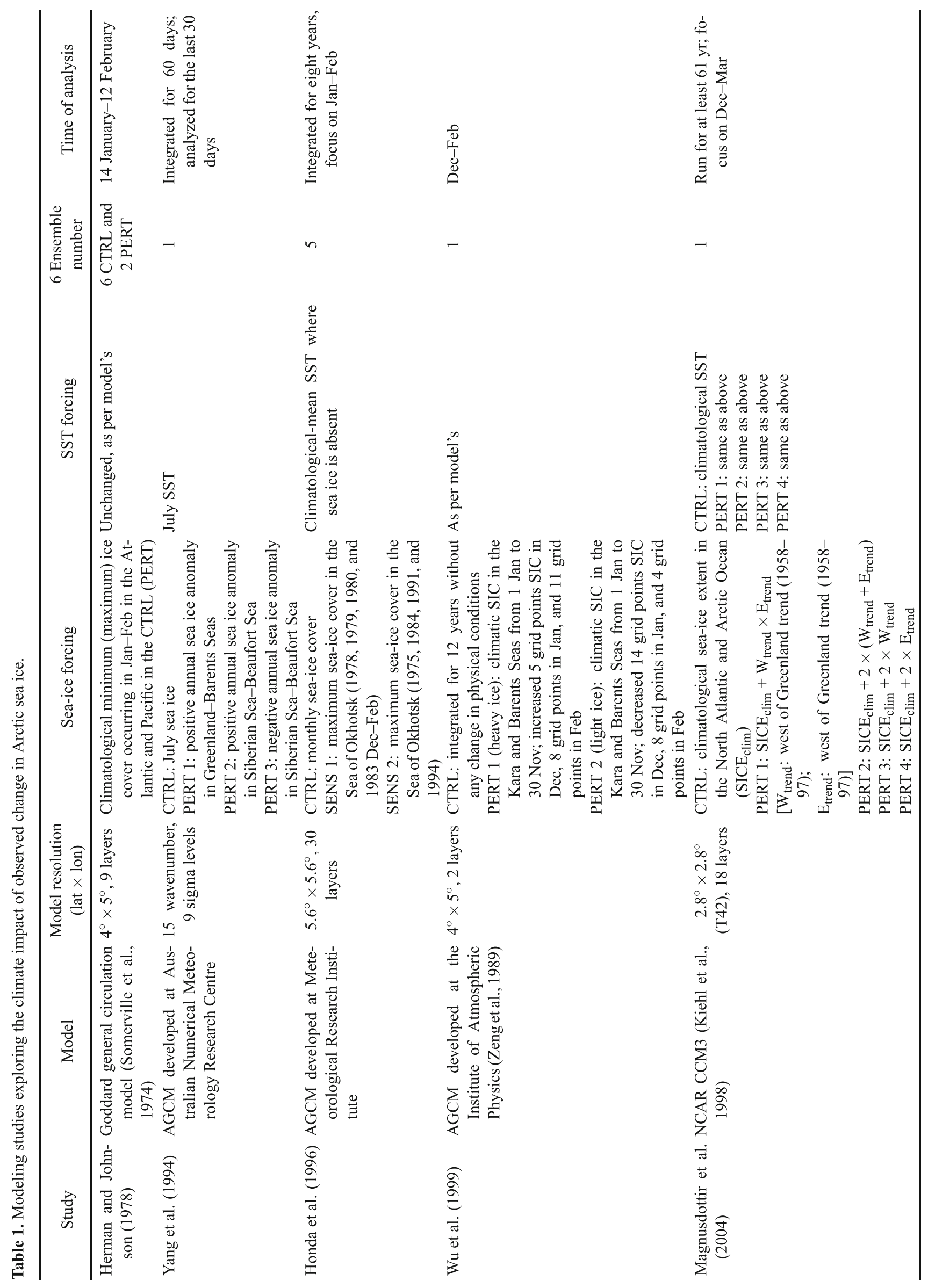




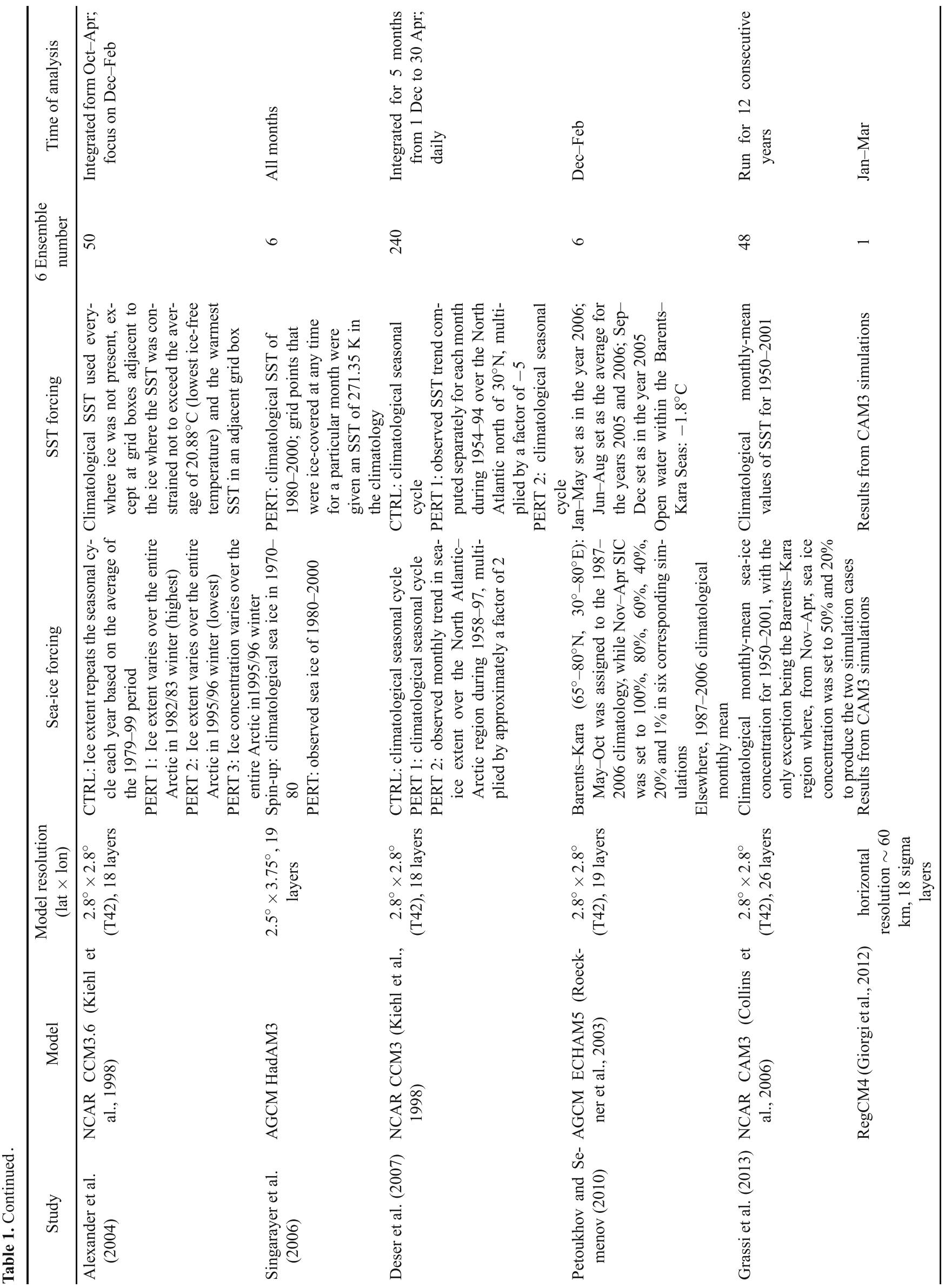




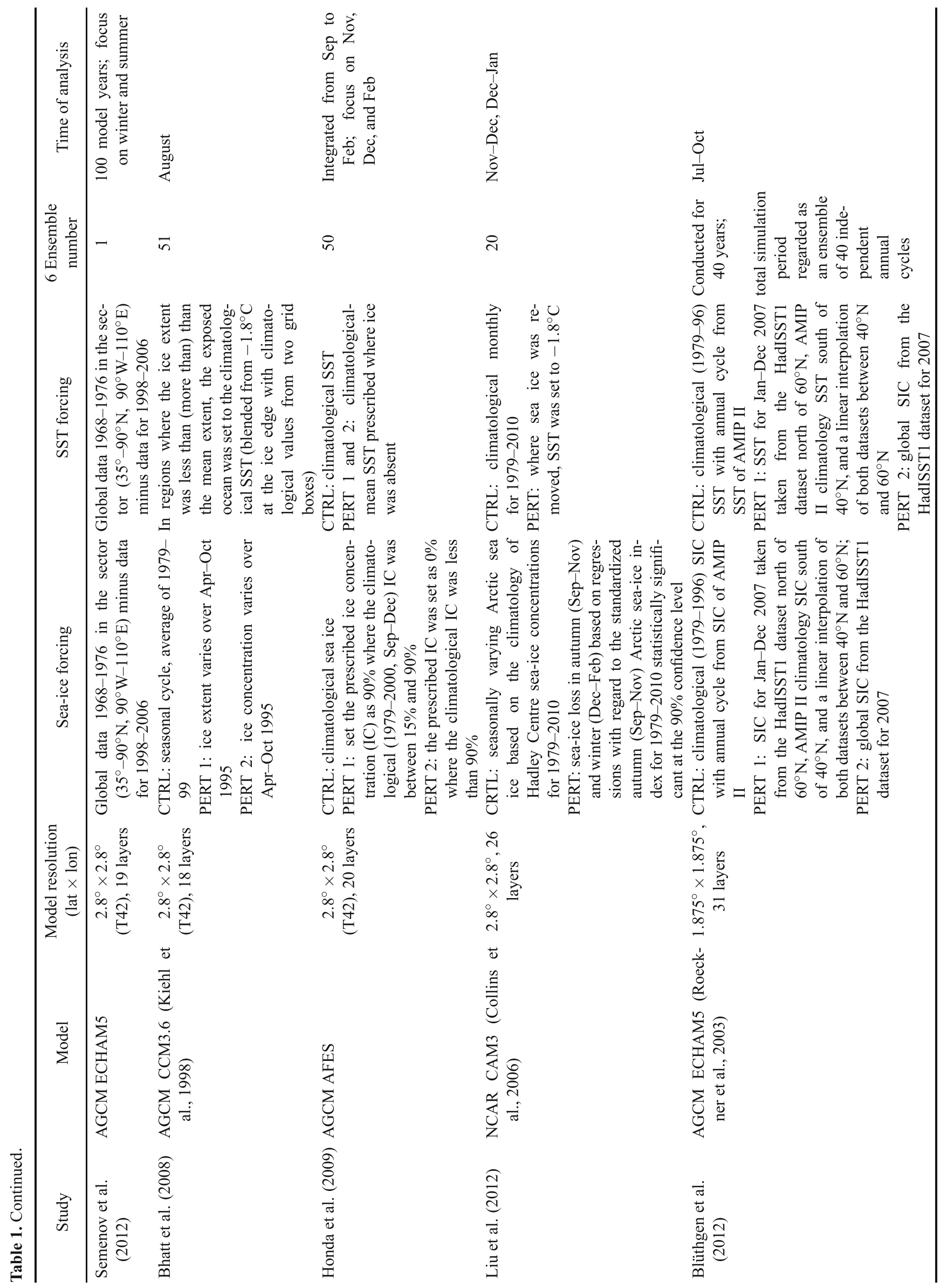




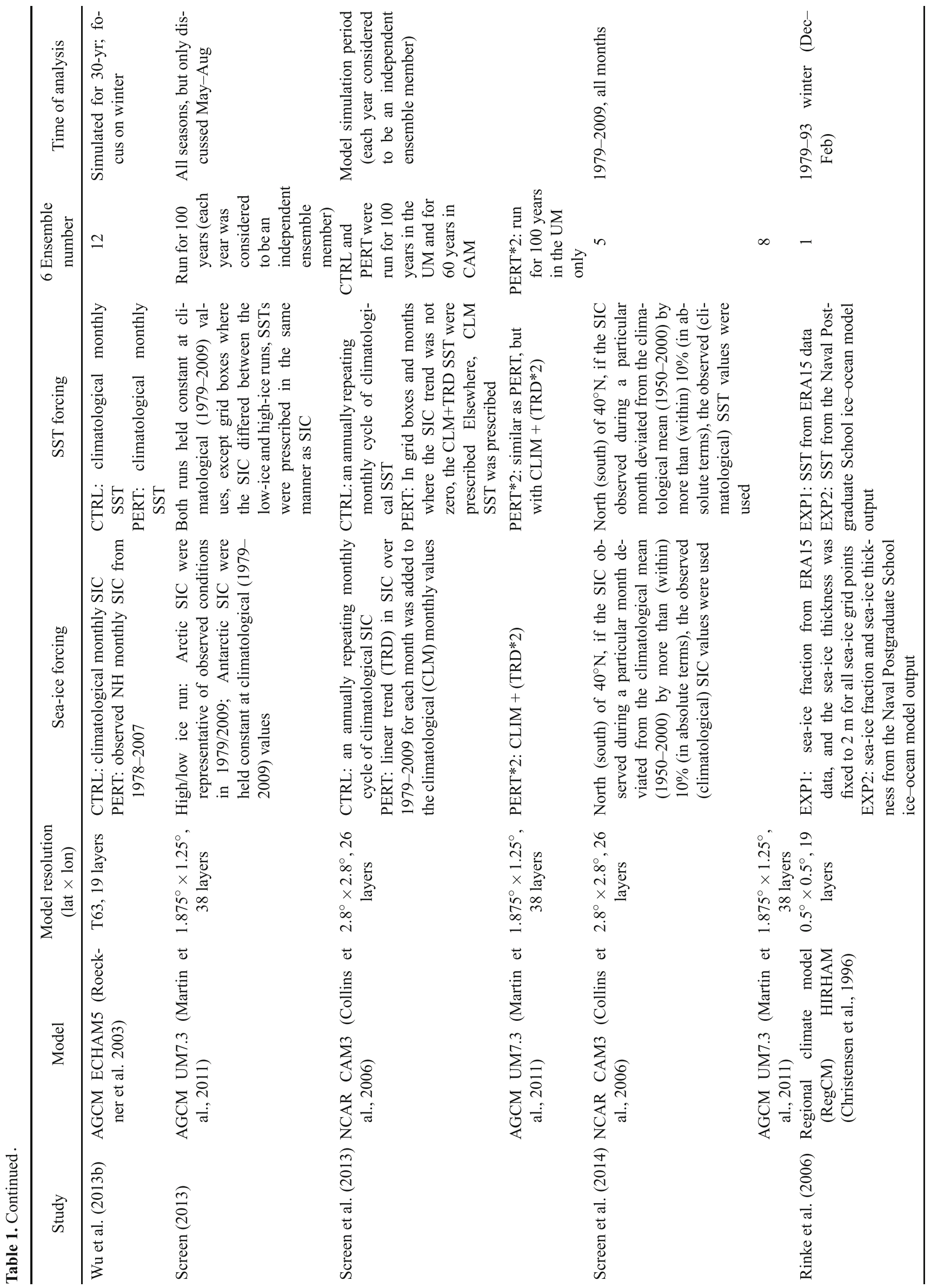




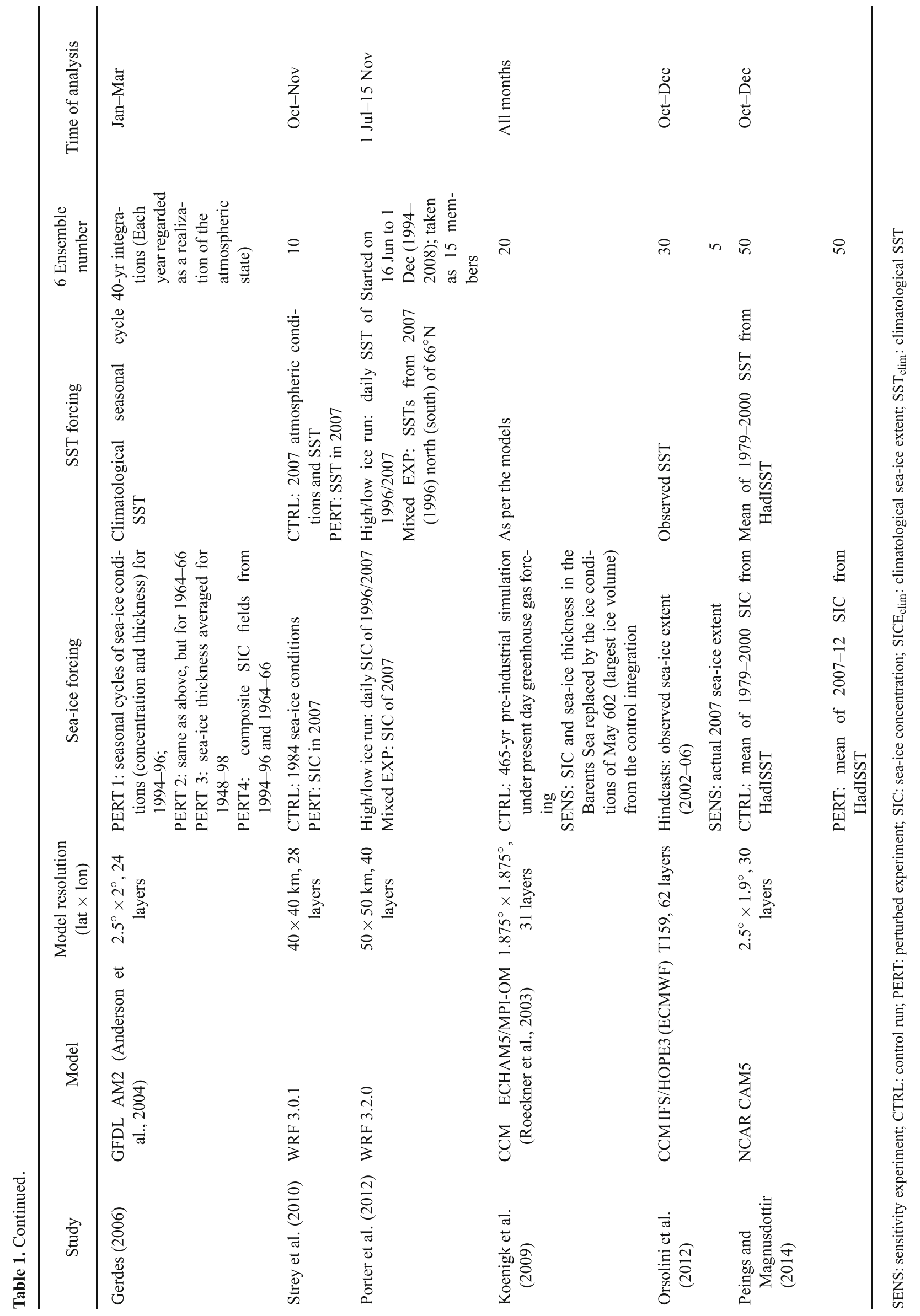




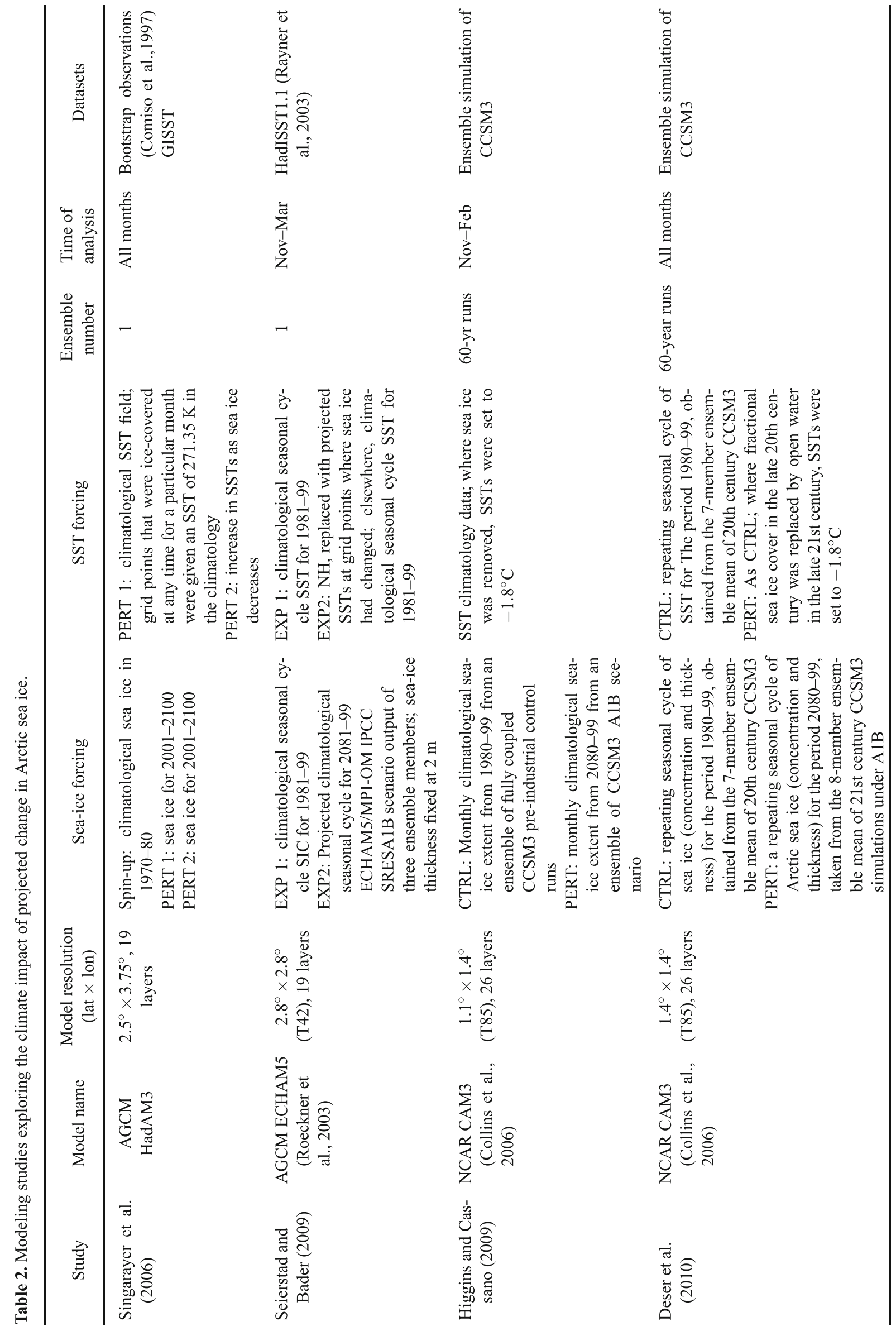




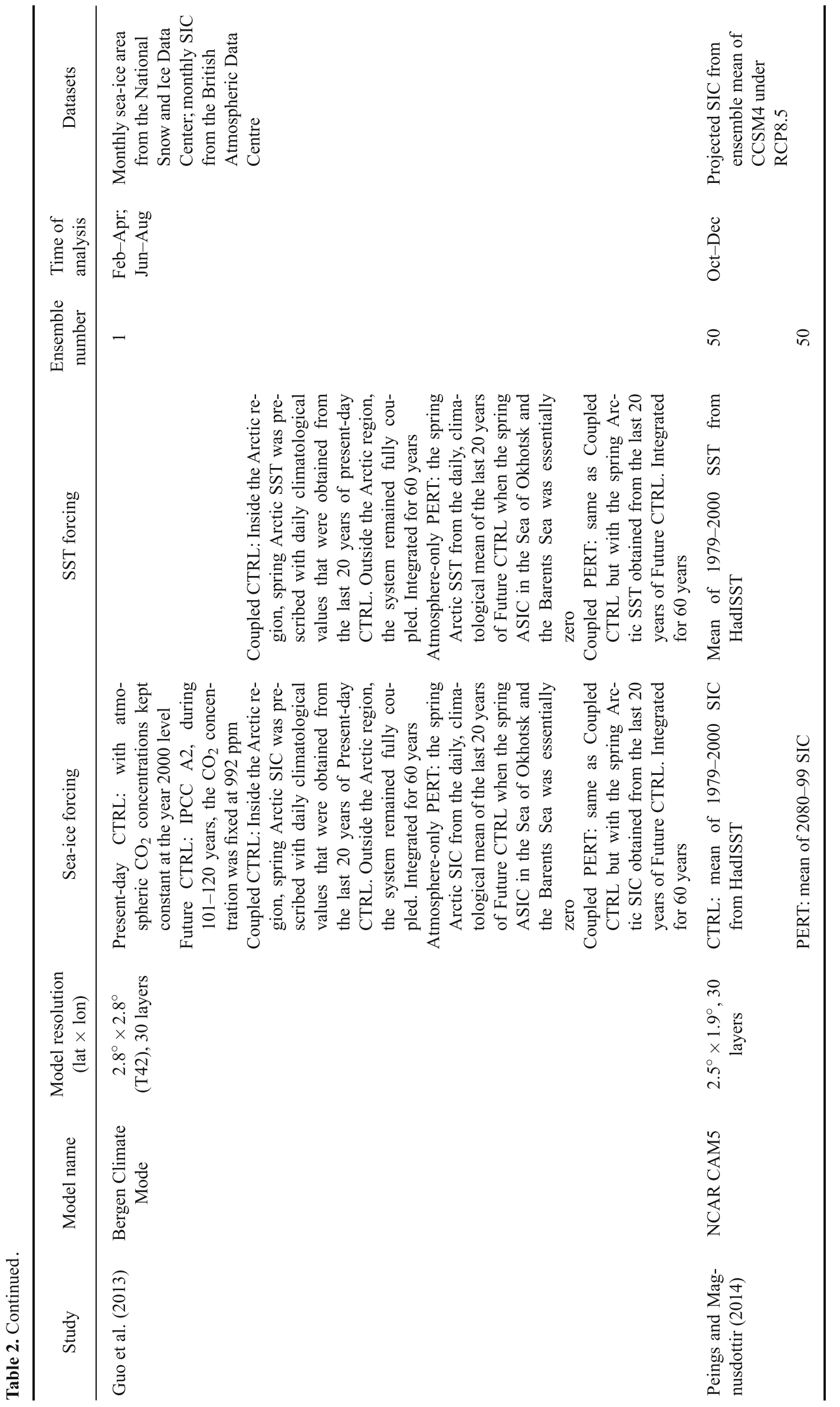


processes and the global climate system. They found that disturbances in the wintertime Arctic sea-ice and snow cover exert a strong influence on the mid- and high-latitude climate by modulating the strength of the sub-polar westerlies and storm tracks. Besides, changes in parameterization of the Arctic sea ice to include the annual cycle and snow albedo could trigger changes in the $\mathrm{AO} / \mathrm{NAO}$. By prescribing different values (50\% and 20\%) of SIC in November-April in the Barents-Kara Seas in CAM3, and by using the simulated results to force RegCM4 (Regional Climate Model version 4), Grassi et al. (2013) investigated the potential impact of Arctic sea-ice reduction during the winter period (January-March) on extreme climate events over the Mediterranean region. The simulations indicated that the large-scale atmospheric circulation response to sea-ice reduction in the Barents-Kara Seas resembles a negative phase of the AO and is characterized by a wave-activity flux from the North Atlantic toward the Mediterranean Basin during winter months. It was suggested that, associated with sea-ice reduction in the BarentsKara Seas, extreme cold events over continental Europe and extreme precipitation events over the entire Mediterranean Basin become more frequent and more intensified.

Petoukhov and Semenov (2010) used the ECHAM5 AGCM to investigate the relationship between cold Eurasian winters and a reduction in wintertime SIC in the BarentsKara Seas. Forced by decreasing SIC in the Barents-Kara Seas, model simulations indicated that lower-tropospheric heating over the Barents-Kara Seas caused by sea-ice reduction could induce strong anticyclonic anomalies over the Polar Ocean and lead to anomalous cold easterly advection over northern Eurasia. By imposing SIC and SST variations in the region of $\left(35^{\circ}-90^{\circ} \mathrm{N}, 90^{\circ} \mathrm{W}-110^{\circ} \mathrm{E}\right)$ during $1968-$ 1976/1998-2006 on ECHAM5, Semenov et al. (2012) suggested that a SIC decrease and a strong warming over the Barents Sea in the winter period could lead to a cooling over vast regions of the northern part of Eurasia, and increase the probability of anomalously cold January months by two times or more (for regions in Western Siberia) by inducing positive pressure anomaly with a center over the southern boundary of the Barents Sea and anomalous advection of cold air masses from the northeast.

\subsubsection{Summer and autumn sea-ice impact}

Bhatt et al. (2008) forced the CCM3 AGCM with reduced realistic summer sea ice in the Arctic in the summer of 1995 (which had the lowest June-September ice extent in the satellite record before 2007) and investigated the atmospheric response, including larger surface fluxes and higher surface air temperatures in the open water area as compared with climatological sea ice. They found that the strongest response took place during the month of August when the Arctic displayed a weak local thermal response with warmer surface air temperatures and lower SLP. The large-scale circulation response to reduced sea ice in the western Arctic was increased SLP over the North Pacific, which was part of a northward expansion of the summertime subtropical high. By imposing heavy/light $(90 \% / 10 \%)$ SIC in an AGCM called AFES
(Atmospheric Component of Earth Simulator) from September to December, Honda et al. (2009) investigated the influences of Arctic sea-ice anomalies (September-December) on the winter atmospheric circulation. They suggested that a reduction of sea ice over the Barents-Kara Seas in the autumn (September) results in anomalous open water in this region. Anomalous turbulent heat fluxes from the additional open water thermally generates a stationary Rossby wave, which tends to induce an amplification of the Siberian high, which in turn causes significant cold anomalies over the Far East in the early winter (December) and zonally elongated cold anomalies from Europe to the Far East in the late winter (February). Liu et al. (2012) forced the NCAR's CAM3.1 with autumn (September-November) SIC anomalies in the Arctic regions, which were significantly related to the winter Eurasia climate in reanalysis data. They suggested that diminishing autumn Arctic sea ice induces positive SLP anomalies over high latitudes and negative SLP anomalies over midlatitudes in winter, accompanied by a significant surface warming in the Arctic Ocean and Greenland and cooling over northern North America, Europe, Siberia, and East Asia. Besides, an increase in specific humidity is found in Europe and North America, which might be responsible for the increased snowfall over Eurasian continents and North America in recent years. They proposed a mechanism in which the response of winter atmospheric circulation to reduced autumn Arctic sea-ice cover bears some resemblance to the negative phase of the AO but with broader meridional meanders in midlatitudes, which would lead to increased cold surges over large parts of northern continents.

\subsubsection{Sea-ice change in all seasons}

Kumar et al. (2010) explored the contribution of seaice loss to the Arctic amplification using three AGCMs [the NCAR's CCM3, the Geophysical Fluid Dynamics Laboratory Atmospheric Model Version 2.1 (GFDL AM2.1), and the NCEP's Global Forecast System (GFS)] forced by monthly observed SST and SIC in 2007 and by monthly observed SST in 2007 and the monthly climatological SIC of 1971-2000. Their results indicated that sea-ice loss did not contribute much to the observed 2007 land surface warming equatorward of $60^{\circ} \mathrm{N}$, although it could essentially explain all of the estimated surface warming over the Arctic Ocean. Blüthgen et al. (2012) used observed 2007 sea-ice conditions to force the ECHAM5 AGCM and found the surface air temperature over northern Siberia and the eastern Arctic to increase by about $3 \mathrm{~K}$ and the oceanic heat uptake to increase by about $40 \mathrm{~W} \mathrm{~m}^{-2}$ in summer, and oceanic heat loss to increase by $60 \mathrm{~W} \mathrm{~m}^{-2}$ in autumn. In addition, they found a pronounced negative SLP anomaly over the eastern Arctic in late summer (July-September).

Wu et al. (2013b) used the ECHAM5 forced by observed northern hemispheric monthly SIC from 1978 to 2007 to explore Arctic sea-ice impact, and their numerical experiments demonstrated the simulated winter atmospheric response to Arctic sea-ice decrease to be dynamically consistent with the observed trend in the tripole wind pattern for winter during 
1979-2012, one of the causes of the observed lower winter SAT trend over Central and East Asia. The results of this study also implied that East Asia might experience more frequent and/or intense winter extreme weather events in association with Arctic sea-ice loss. Screen et al. (2014) prescribed the observed variations of monthly (1979-2009) Arctic SIC in experiments performed with two different AGCMs. A slight negative NAO-like response was found in early winter (November-December); however, the NAO-type response was quite weak and often masked by intrinsic (unforced) atmospheric variability. They suggested that the potential remote responses to Arctic sea-ice change were hard to confirm and remained uncertain. By prescribing different seaice conditions (using 1979 as a high ice run and 2009 as a low ice run) with annually repeating monthly cycles but holding other forcings constants in the UK Met Office's Unified Model (UM) version 7.3, Screen (2013) suggested that Arctic sea-ice loss induces a southward shift of the summer (JuneAugust) jet stream over Europe and increases northern European summer precipitation. Peings and Magnusdottir (2014) used CAM5 with observed mean SICs for 1979-2000 and 2007-2012 in separate experiments to suggest that a change in sea ice could have caused the cooling in the midlatitudes in recent winters. The anomalous Rossby waves trigged by the sea-ice change could penetrate into the stratosphere in late winter (February) and weaken the stratospheric polar vortex to generate negative NAO anomalies that propagate downwards after several weeks.

\subsubsection{Regional model simulation}

Regional climate models have also been used to examine the atmospheric response to altered sea-ice conditions. Most studies in this area have focused on the local atmospheric response to reduced Arctic sea ice. The local impact includes a heated and moistened atmosphere and increased cloud cover.

Rinke et al. (2006) forced the atmospheric regional climate model HIRHAM over an Arctic domain with two different winter (December-February) sea ice and SST boundary conditions, but exactly the same lateral boundary conditions. Areas of higher SSTs and reduced sea-ice thickness and concentration were associated with stronger upward heat fluxes and higher 2-m air temperatures. They did not find a simple relationship between anomalies in SST, sea ice, and changes in storm tracks, which they argued may have resulted from a dominance of the lateral boundary forcing. Semmler et al. (2004) studied atmospheric impacts using two regional climate model experiments focused over the Fram Strait region. The experiments differed in the treatment of sea ice-one experiment had sea ice prescribed by satellite data, and therefore grid cells could have partial sea ice, while in the other experiment the sea ice was either 0 or $100 \%$, depending on the SST. In the experiment with more realistic sea ice, turbulent heat fluxes were often directed upwards due to the presence of leads and polynyas, leading to an increase in cloud cover and precipitation. The experiment with more realistic sea ice also compared more favorably to observations. Strey et al. (2010) used the Polar Weather Research and Forecast- ing (WRF) model (Polar WRF) with the southern boundary at about $30^{\circ} \mathrm{N}$ to explore the 2007 sea-ice impact. The simulations used 2007 lateral atmospheric boundary conditions and SSTs for September-December. For the ensemble members testing the impact of decreased sea ice, the 2007 SIC was used; while for the control ensemble members, the 1984 SIC and extent were employed. Focusing their results on October-November, they found increased latent heat fluxes and large temperature increases over the area of anomalous open water (focused in the western Arctic) and also over the Gulf Stream area, which they attributed to a decrease in SLP over eastern North America and an associated increase in cold air advection in this area. Difference maps showed a "trough-ridge-trough" pattern from the area of anomalous open water (a large decrease in SLP) roughly to the North Atlantic where positive SLP anomalies were modelled. In general, the simulations showed circulation changes throughout the atmosphere with higher tropospheric heights over western North America and lower constant pressure heights over eastern North America in the 2007 sea ice case, with these features broadening with height.

The subsequent WRF-based study by Porter et al. (2012) used observed sea ice and SSTs from a low (2007) and high (1996) ice year, in addition to an experiment using a mixed SST field between 2007 and 1996, for three 15-member ensembles to sample a large range of climatic variability. They found the largest local response in October and November with increased turbulent heat fluxes, which heated and moistened a vertically deep layer of the atmosphere. They also found an increase in cloud cover affecting the surface and atmospheric energy budgets. Studies with global (Blüthgen et al., 2012) and regional (Porter et al., 2012) models have analyzed ensemble runs with prescribed sea-ice extent of the record minimum in 2007. They confirm the idea that increased oceanic heat uptake over the Arctic in summer is followed by increased oceanic heat release to the atmosphere in autumn, resulting in higher SATs, stronger heat fluxes and increased humidity.

\subsubsection{Sea-ice impact by CCMs}

Orsolini et al. (2012) performed hindcast simulations with the ECMWF's high-resolution coupled ocean-atmosphere seasonal forecast model to analyze the impact of the 2007 sea-ice minimum on the following autumn and early winter (October-December) atmospheric response. It was found that the most obvious positive surface temperature anomalies (as high as $10^{\circ} \mathrm{C}$ ) appeared over the Pacific and Siberia in October and November. By December, intensified surface highs emerged on the American and Eurasian continents, which were associated with anomalous advection of cold (warm) polar air on their eastern (western) sides, bringing cooler temperatures along the Pacific coast of Asia and northeastern North America. Over the oceans, the low pressure systems (i.e., the Aleutian and Icelandic lows) were deepened and the tropospheric jets were intensified. In addition to sea-ice extent anomalies, realistic sea-ice thickness changes could also induce an atmospheric response. Using GFDL AM2 forced 
by maximum (1964-66) and minimum (1994-96) Arctic seaice volume conditions, Gerdes (2006) suggested that a thinning of Arctic sea-ice thickness could lead to negative SLP anomalies in the central Arctic and positive ones over the subtropical North Atlantic, resembling the positive phase of NAO.

\subsubsection{Response to projected sea ice}

Fletcher (1968) was among the first to speculate on the climate impact of extreme Arctic sea-ice conditions. He suggested that an ice-free Arctic would cause weaker meridional temperature gradients and a weaker zonal circulation, and would be accompanied by more high-latitude snowfall due to increased evaporation over the Arctic Ocean. Newson (1973) was among the first to use an AGCM for illustrating the climate impact of a full removal of winter Arctic sea-ice cover with the Arctic SST at freezing point. The simulated response showed surface warming over the Arctic basin with a maximum warming of $40^{\circ} \mathrm{C}$, and a surface cooling over the northern midlatitude continents (cooling over Eurasia could reach $-6^{\circ} \mathrm{C}$; Newson, 1973, Fig. 1). Newson noticed a distinct southward movement and weakening of the prevailing midlatitude westerlies in response to the removed winter Arctic sea ice. Newson also suggested that a weakening of midlatitude westerlies could lead to a more blocked atmospheric circulation. Singarayer et al. (2006) forced the Hadley Centre Atmospheric Model (HadAM3) with predicted sea-ice reductions until 2100 under one moderate scenario and one severe scenario of ice decline and revealed that significant warming at high latitudes could occur during the 21 st century, and that parts of Europe may experience higher precipitation rates due to the intensification of storm tracks. Significant increases in SAT during 2090-99 might occur primarily in winter, primarily due to large upward sensible heat flux from the ocean directly over the areas within the ice extent where open water has increased. Seierstad and Bader (2009) forced ECHAM5 with the projected climatological seasonal cycle of Arctic sea ice at the end of 21st century (2081-99) and found the storminess during December and January in the midlatitudes to display significant reductions associated with projected negative anomalies of sea ice. The projected decrease in storminess predicted to hit Europe further to the south might be related to a negative phase of the NAO. Higgins and Cassano (2009) forced CAM3 with climatological sea ice from 1980 to 1999 and climatological sea-ice extent from 2080 to 2099 from an ensemble of CCSM3 A1B scenario runs with the aim to assess the direct impact of sea ice on winter (November-February) Arctic atmospheric circulation, precipitation, and temperature. They found that, associated with reduced sea ice, the Aleutian lows in winter (November-February) deepen and the geopotential height at $1000 \mathrm{hPa}$ increases. Besides, large increases in precipitation were found across the Arctic, mainly due to thermodynamic changes such as increased moisture in the atmosphere, rather than changes in the frequency of cyclones. Deser et al. (2010) also used CAM3 to ascertain the atmospheric response to projected Arctic sea-ice conditions for 2080-99 from the A1B scenario using an eight-member ensemble mean of CCSM3 simulations. Even though the loss of Arctic sea ice was greatest in summer and autumn (July-November), it was projected that the response of the net surface energy budget over the Arctic Ocean to sea-ice loss would be largest in winter (October-February). Besides, the air temperature and precipitation responses were greatest in November-December over Siberia and northern Canada, with values of $\sim 7^{\circ} \mathrm{C}$ and $\sim 0.16 \mathrm{~mm} \mathrm{~d}^{-1}$, respectively. As a result of enhanced winter precipitation (and despite the warmer air temperatures), snow depths over Siberia and northern Canada were projected to increase by $\sim 1 \mathrm{~cm}$ liquid water equivalent in late winter (February-April). Guo et al. (2014) used both the atmospheric component of the Bergen Climate Model and the complete Bergen Climate Model to investigate the mechanism by which the change in spring Arctic sea ice impacts the EASM. They set up numerical experiments using projected spring Arctic sea ice and projected SST where the sea ice had been removed in the Arctic, and found that the SST anomalies in the North Pacific bridged the spring Arctic sea ice and the EASM. Change in the spring Arctic sea-ice cover could lead to SST change in the North Pacific, possibly persisting into summer and therefore influencing the EASM. The mediating role of SST changes was highlighted by the result that only the atmosphere-ocean general circulation model (AOGCM), and not the AGCM, reproduced the observed sea ice-EASM linkage. Peings and Magnusdottir (2014) used CAM5 with observed and projected mean SICs for 1979-2000 and 208099 , respectively. They only found negative NAO anomalies in the troposphere and weakened westerlies as a result of tropospheric thermal expansion. The thermodynamic response beyond the Arctic offsets the dynamic response, implying that strong Arctic sea-ice forcing has a limited impact on the intensity of cold extremes in the midlatitudes. Although model simulation results show that the Arctic Ocean circulation changes in response to doubled $\mathrm{CO}_{2}$ in the atmosphere (Gao et al., 2009), it is difficult for atmosphere-only models to explore the response of ocean circulation to sea-ice anomalies.

\section{Uncertainty in the Arctic sea-ice impact}

Most of the studies summarized in this paper used satellite data, reanalysis products and numerical models. As reviewed by Budikova (2009) and Vihma (2014), there are uncertainties, which are difficult to quantify, related to all of these approaches. Therefore, there are also uncertainties in the conclusions of these studies, as well as those that subsequently cite their data and findings. In this section, we focus on reviewing current understanding of the uncertainties that originate from the atmosphere's internal variability and associated pathways.

\subsection{Uncertainty in the atmospheric response}

Although all CMIP3 and CMIP5 models project a decline in Arctic sea ice in the 21 st century, the AO shows a posi- 
tive trend in CMIP3 but a negative trend in CMIP5 (Cattiaux and Cassou, 2013). This discrepancy implies that Arctic seaice feedback is not a dominant factor regulating the AO in these models. Seierstad and Bader (2009) used ECHAM5 to explore the impact of projected Arctic sea-ice cover on wintertime extratropical storminess and the NAO. As the Arctic sea-ice cover continues to decline, the storminess tends to decrease during December and January in both mid and high latitudes, which is also related to the negative phase of the NAO. Such a negative phase of the NAO in late winter is induced by the projected Arctic sea-ice reduction for all seasons. By forcing CAM5 with two different sea-ice forcings representing the recent (2007-12) and projected (208099) sea-ice decline over the Arctic, Peings and Magnusdottir (2014) examined the impact of the Arctic sea-ice decline on the northern hemispheric atmospheric circulation and extreme cold temperatures over the midlatitudes. The numerical experiments forced by the recent sea-ice conditions indicated that anomalous Rossby waves could penetrate into the stratosphere in late winter (February) and lead to negative anomalies of the AO penetrating downward, further leading to cold land surface temperatures over the midlatitudes. The numerical experiments forced by projected sea-ice conditions also showed a negative phase of the tropospheric AO in early and late winter, mainly driven by a large warming of the lower troposphere over the Arctic. Owing to the large lower tropospheric warming that extended well beyond the Arctic, the stronger sea-ice forcing had a limited impact on the intensity of cold extremes over the midlatitudes. Using ECHAM5, Semenov et al. (2012) investigated the sensitivity of Eurasian winter and summer SAT to variations in SST and SIC during 1998-2006 and 1968-1976. They found that the variations of SST and SIC could account for the SAT variations in Western Europe, but could not explain the warming in Eastern Europe and western Siberia. By checking the coincidence between occurrences of European cold winter months and sea-ice reduction over the Barents-Kara Seas in 13 CMIP5 models simulations for the 21st century (2006-2100) under two Representative Concentration Pathway (RCP) scenarios (RCP4.5 and RCP8.5), Yang and Christensen (2012) suggested that a moderate reduction of SIC in the Barents-Kara Seas between 2006 and 2050 will likely provide favorable conditions for the occurrence of cold winters in Europe. Earlier studies also suggested that the winter atmospheric circulation response to autumn Arctic sea-ice reduction contains large uncertainties. For example, some studies show that a negative-AO-like pattern could persist into winter (Francis et al., 2009; Liu et al., 2012, 2013; Li and Wang, 2013b), while other studies (Blüthgen et al., 2012; Screen et al., 2014) argue that autumn atmospheric circulation anomalies cannot continue into winter. In addition, Screen et al. (2013) and Liu et al. (2012) reported contrasting winter $\mathrm{AO}$ tendencies in response to the autumn Arctic SIC trend using CAM3. This contrast could have been caused by either the different sizes of ensemble members or the difference in boundary conditions. For example, the Arctic SIC and associated SST during the whole year were used in Screen et al. (2014), whereas only the autumn and partial winter (persisting from autumn) SIC changes were used in Liu et al. (2012).

Cohen et al. (2012) suggested that Arctic sea-ice loss in September, poleward of $65^{\circ} \mathrm{N}$, could lead to an increase of Eurasian snow cover in October due to the potential contribution to tropospheric moisture. The increasing snow cover then results in stronger diabatic cooling and a strengthened Siberian high in autumn and winter. This further leads to an increase in the upward propagation of planetary waves and a weakened polar vortex and westerlies. Consequently, a negative $\mathrm{AO}$ emerges in the lower troposphere and increased Arctic cold air outbreaks in the midlatitudes. Grassi et al. (2013) suggested that, associated with sea-ice reduction in the Barents-Kara Seas, extreme cold events over continental Europe and extreme precipitation events over the entire Mediterranean Basin become more frequent and intense. The large-scale atmospheric circulation response to sea-ice reduction in the Barents-Kara Seas resembled the negative phase of the AO. It was also suggested that the increase in snowfall over the United States and Europe could be attributed to an increase in the frequency of blocking events caused by the recent autumn Arctic sea-ice loss (Liu et al., 2012). However, Liu et al. (2012) argued that the change in atmospheric circulation in response to reduced autumn Arctic sea-ice cover is different from the classic AO, with broader meridional meanders in midlatitudes. In addition to autumn sea ice, summer Arctic sea-ice variability could have an impact on large-scale northern hemispheric atmospheric circulation (Overland and Wang, 2010). It is suggested that a reduction of summer Arctic sea-ice extent leads to more open water in late summer, and the stored additional heat in the Arctic Ocean is released to the atmosphere during the following autumn season. As a result, the SAT during late autumn is higher than normal, contributing to an increase in the 1000-500 hPa thickness field, which favors westerly wind flow associated with the polar vortex. Therefore, cold polar air moves south to the midlatitudes.

Unlike the impact pathways revealed by other studies, $\mathrm{Wu}$ et al. (2013a) suggested that autumn Arctic sea-ice loss is significantly correlated with the negative phase of the tripole wind pattern during winter. The negative phase of the tripole wind pattern corresponds to an anomalous anticyclone over northern Eurasia, as well as two anomalous cyclones that occur over southern Europe and in the mid-high latitudes of East Asia. These anomalous cyclones in turn lead to enhanced winter precipitation in these two regions, as well as negative surface temperature anomalies over the mid-high latitudes of Asia. Petoukhov and Semenov (2010) argued that changes in the November sea-ice cover in the Barents Sea could lead to an additional heat source and intensified cyclones in downstream Arctic regions in the following months, which is similar to a limitation of the NAO/AO in the troposphere with cold anomalies over the northern continents, potentially adding to anomalies directly induced by a negative AO.

Francis and Vavrus (2012) suggested that the Arctic warming could lead to a meandering jet stream (especially 
in autumn and winter), a slow-down of the eastward progression of Rossby waves, and ultimately more persistent weather patterns in the midlatitudes. However, as we and others have summarized, this mechanism is still under debate.

\subsection{Atmospheric internal variability}

Based on model simulations, Screen et al. (2013, 2014) proposed that the local response (near-surface atmospheric warming and precipitation) to the Arctic sea-ice reduction can be easily detected in observational records with high signal-to-noise ratios. However, the atmospheric circulation response (SLP and upper-level geopotential heights) and the response over the midlatitudes could be partially or fully masked by the atmospheric internal variability (AIV). In Wu et al. (2013b), only 5 members of a total of 12 experiments forced by the observed sea-ice conditions from 1978-2007 could reproduce the observed anomalous SAT and atmospheric circulation patterns. This also implies the potential importance of the AIV. The results in the simulations with small-size ensembles are likely incapable of eliminating the AIV by using the ensemble mean and therefore are less reliable (Screen et al., 2013). Honda et al. (2009) used 28 of a total of 50 experiments to explore the link between the autumn Arctic sea-ice reduction and Eurasian cold winters. They found that the signal was weaker when all 50 experiments were used, albeit the tendencies were similar. They proposed that this was likely related to the preconditioning of the atmospheric state. Kumar et al. (2010) estimated the simulated internal variability of SAT and suggested that the sea-ice reduction signal in SAT is highly detectable over the Arctic Ocean, whereas it can be masked by internal variability for the SAT over land between $50^{\circ} \mathrm{N}$ and $60^{\circ} \mathrm{N}$.

\section{Summary and future perspective}

This paper reviews the available literature on the climatic impact of Arctic sea ice, with a special focus on Eurasia. The main findings can be summarized as follows:

- Arctic sea ice exhibits multidecadal variability. The multidecadal variations of Arctic sea ice are likely governed by the poleward ocean heat transport related to Atlantic multidecadal variability (also referred to as the AMO, at least for the Arctic sea-ice variations in the Atlantic sector).

- Arctic sea-ice decline during the satellite era is likely a consequence of multidecadal variation and anthropogenic forcing.

- The climatic impact of changes in Arctic sea ice in different seasons has been addressed, but most of the focus has been on the reduction of autumn and winter Arctic sea ice.

- Paleo-studies suggest that a reduction of Arctic sea ice could cause surface warming at mid and high latitudes, and has the potential to affect the glacial-interglacial cycle.

- A mechanism of negative feedback between the Arctic sea ice and the AO/NAO has been suggested. However, there is debate as to whether the reduction in autumn Arcticsea-ice-induced negative AO/NAO can persist into winter.
There are also modelling studies that do not show the negative AO/NAO response to the reduction in autumn Arctic sea ice.

- There are studies that suggest a change in autumn Arctic sea ice could have caused the recent Eurasian cooling, either by a negative $\mathrm{AO}$ or AO-like response or an intensified Siberian high. There are also studies that suggest winter atmospheric circulation is more closely associated with changes in winter Arctic sea ice.

- Changes in spring Arctic sea ice have been linked to the summer precipitation in East Asia though different suggested pathways.

- The reduction of autumn Arctic sea ice has also been linked to the increase in spring snowfall and cooling over Eurasia.

- The link between the AO and the EAWM is stronger after the 1980s. The sea-ice reduction related to surface warming over the Arctic has caused change in the meridional temperature gradient and thus led to westward penetration of the East Asian jet stream, strengthening the impact of the AO on the EAWM.

- A link between the Arctic and the midlatitudes has been suggested via changes in planetary waves; however, the pathways involved have not yet been clearly demonstrated.

- Modeling studies suggest that the remote climate response (e.g., atmospheric circulation, air temperature) to the change in Arctic sea ice is hard to detect.

In the future, long-term and reliable data are needed to consolidate understanding of the sea-ice impact on the climate over Eurasia. In addition, coordinated multi-model ensemble experiments with identical sea ice and SST boundary conditions are needed to understand the associated mechanisms. Along with improvements in models, the representation of troposphere-stratosphere interaction should receive more attention. Finally, comparisons between AGCM and CGCM results should be performed to assess the role of twoway coupling.

Acknowledgements. This work was supported by the Research Council of Norway through the BlueArc project (207650/ E10), the European Union 7th Framework Programme (FP7 20072013) through the NACLIM project (308299), and the National Natural Sciences Foundation of China through projects 41375083 and 41210007. This work also contributes to the NordForsk-funded project GREENICE (61841): Impacts of Sea-Ice and Snow-Cover Changes on Climate, Green Growth, and Society.

Open Access. This article is distributed under the terms of the Creative Commons Attribution License which permits any use, distribution, and reproduction in any medium, provided the original author(s) and the source are credited.

\section{REFERENCES}

Alexander, M. A., U. S. Bhatt, J. E. Walsh, M. Timlin, and J. S. Miller, 2004: The atmospheric response to realistic Arctic sea ice anomalies in an AGCM during winter. J. Climate, 17, 
890-905.

Bader, J., D. S. M. Michel, K. I. Hodges, N. Keenlyside, S. Østerhus, and M. Miles, 2011: A review on Northern Hemisphere sea-ice, storminess and the North Atlantic Oscillation: Observations and projected changes. Atmos. Res., 101, 809-834.

Ballantyne, A. P., Y. Axford, G. H. Miller, B. L. Otto-Bliesnere, N. Rosenbloome, and J. W. C. Whitec, 2013: The amplification of Arctic terrestrial surface temperatures by reduced sea-ice extent during the Pliocene. Palaeogeography, Palaeoclimatology, Palaeoecology, 386, 59-67.

Barnes, E. A., 2013: Revisiting the evidence linking Arctic amplification to extreme weather in midlatitudes. Geophys. Res. Lett., 40, 4734-4739.

Bhatt, U. S., M. A. Alexander, C. Deser, J. E. Walsh, J. S. Miller, M. Timlin, J. D. Scott, and R. Tomas, 2008: The atmospheric response to realistic reduced summer Arctic sea ice anomalies. Arctic Sea Ice Decline: Observations, Projections, Mechanisms, and Implications, E. T. DeWeaver, C. M. Bitz, and L. B. Tremblay, Eds., Geophys. Monogr. Ser., Vol. 180, AGU, Washington, D. C., 91-110.

Blüthgen, J., R. Gerdes, and M. Werner, 2012: Atmospheric response to the extreme Arctic sea-ice conditions in 2007. Geophys. Res. Lett., 39, L02707, doi: 10.1029/2011GL050486.

Budikova, D., 2009: Role of Arctic sea ice in global atmospheric circulation: A review. Global and Planetary Change, 68, 149-163.

Cassano, E. N., J. J. Cassano, M. E. Higgins, and M. C. Serreze, 2013: Atmospheric impacts of an Arctic sea ice minimum as seen in the Community Atmosphere Model. Int. J. Climatol., 34(3), 766-779. doi: 10.1002/joc.3723.

Cattiaux, J., and C. Cassou, 2013: Opposite CMIP3/CMIP5 trends in the wintertime Northern Annular Mode explained by combined local sea ice and remote tropical influences. Geophys. Res. Lett., 40, 3682-3687.

Cohen, J. L., J. C. Furtado, M. A. Barlow, V. A. Alexeev, and J. E. Cherry, 2012: Arctic warming, increasing snow cover and widespread boreal winter cooling. Environ. Res. Lett., 7(1), doi: 10.1088/1748-9326/7/1/014007.

Comiso, J. C., C. L. Parkinson, R. Gersten, and L. Stock, 2008: Accelerated decline in the Arctic sea ice cover. Geophy. Res. Lett., 35, L01703, doi: 10.1029/2007GL031972.

Day, J. J., J. C. Hargreaves, J. D. Annan, and A. Abe-Ouchi, 2012: Sources of multi-decadal variability in Arctic sea ice extent. Environ. Res. Lett., 7, 034011, doi: 10.1088/1748-9326/7/3/ 034011.

Deser, C., and H. Teng, 2008: Evolution of Arctic sea ice concentration trends and the role of atmospheric circulation forcing, 1979-2007. Geophys. Res. Lett., 35, L02504, doi: 10.1029/ 2007 GL032023.

Deser, C., G. Magnusdottir, R. Saravanan, and A. S. Phillips, 2004: The effects of North Atlantic SST and sea ice anomalies on the winter circulation in CCM3: Part II. Direct and indirect components of the response. J. Climate, 17, 877-889.

Deser, C., R. A. Thomas, and S. Peng, 2007: The transient atmospheric circulation response to North Atlantic SST and sea ice anomalies. J. Climate, 20, 4751-4767.

Deser, C, R. Tomas, M. Alexander, and D. Lawrence, 2010: The seasonal atmospheric response to projected Arctic sea-ice loss in the late twenty-first century. J Climate, 23, 333-351.

Dethloff, K., and Coauthors, 2006: A dynamical link between the Arctic and the global climate system. Geophys. Res. Lett., 33, L03703, doi: 10.1029/2005GL025245.
Ding, Q. H., J. M. Wallace, D. S. Battisti, E. J. Steig, A. J. E. Gallant, H.-J. Kim, and L. Geng, 2014: Tropical forcing of the recent rapid Arctic warming in northeastern Canada and Greenland. Nature, 509, 209-212.

Dowsett, H., and Coauthors, 2010: The PRISM3D paleoenvironmental reconstruction. Stratigraphy, 7(2-3), 123-139.

Fletcher, J. O., 1968: The influence of Arctic pack ice on climate. Meteor. Monogr., 30, 93-99.

Francis, J. A., 2013: The where and when of wetter and drier: disappearing Arctic sea ice plays a role. Environ. Res. Lett., 8, doi: 10.1088/1748-9326/8/4/041002.

Francis, J. A., and S. J. Vavrus, 2012: Evidence linking Arctic amplification to extreme weather in mid-latitudes. Geophys. Res. Lett., 39, L06801, doi: 10.1029/2012GL051000.

Francis, J. A., W. Chan, D. J. Leathers, J. R. Miller, and D. E. Veron, 2009: Winter Northern Hemisphere weather patterns remember summer Arctic sea ice extent. Geophys. Res. Lett., 36, L07503, doi: 10.1029/2009GL037274.

Frankignoul, C., N. Sénnechael, and P. Cauchy, 2014: Observed atmospheric response to cold season sea ice variability in the Arctic. J. Climate, 27, 1243-1254.

Gao, Y., H. Drange, O. M. Johannessen, and L. H. Pettersson, 2009: Sources and pathways of 90Sr in the North AtlanticArctic region: Present day and global warming. Journal of Environmental Radioactivity, 100, 375-395.

Gerdes, R., 2006: Atmospheric response to changes in Arctic sea ice thickness. Geophys. Res. Lett., 33, L18709, doi: 10.1029/ 2006 GL027146.

Gildor, H., and E. Tziperman, 2000: Sea ice as the glacial cycles' climate switch: Role of seasonal and orbital forcing. Paleoceanography, 15(6), 605-615.

Gildor, H., Y. Ashkenazy, E. Tziperman, and I. Lev, 2013: The role of sea ice in the temperature-precipitation feedback of glacial cycles. Climate Dyn., 43, 1001-1010. doi: 10.1007/s00382013-1990-7.

Grassi, B., G. Redaelli, and G. Visconti, 2013: Arctic sea ice reduction and extreme climate events over the Mediterranean region. J. Climate, 26(24), 10101-10110.

Gulev, S. K., Latif, M., Keenlyside, N., Park, W., and Koltermann, K. P., 2013: North Atlantic Ocean control on surface heat flux on multidecadal timescales. Nature, 499, 464-468.

Guo, D., Y. Q. Gao, I. Bethke, D. Y. Gong, O. M. Johannessen, and H. J. Wang, 2014: Mechanism on how the spring Arctic sea ice impacts the East Asian summer monsoon. Theor. Appl. Climatol., 115, 107-119, doi: 10.1007/s00704-013-0872-6.

He, S. P., 2013: Reduction of the East Asian winter monsoon interannual variability after the mid-1980s and possible cause. Chinese Sci. Bull., 58(12), 1331-1338.

He, S. P., and H. J. Wang, 2013a: Oscillating Relationship between the East Asian Winter Monsoon and ENSO. J. Climate, 26(24), 9819-9838.

He, S. P., and H. J. Wang, 2013b: Impact of the November/ December Arctic Oscillation on the following January temperature in East Asia. J. Geophys. Res., 118, 12981-12998.

He, S. P., H. J. Wang, and J. P. Liu, 2013: Changes in the relationship between ENSO and Asia-Pacific mid-latitude winter atmospheric circulation. J. Climate, 26, 3377-3393.

Herman, G. F., and Johnson, W.T., 1978. The sensitivity of the General Circulation to Arctic sea ice boundaries: a numerical experiment. Mon. Wea. Rev., 106, 1649-1664.

Higgins, M. E., and J. J. Cassano, 2009: Impacts of reduced sea ice on winter Arctic atmospheric circulation, precipitation, and 
temperature. J. Geophys. Res., 114, D16107, doi: 10.1029/ 2009JD011884.

Hildebrandsson, H. H., 1914: Quelques recherches sur les centres d'action de l'atmosphère. Kongl Svenska Vetenskapsakademiens Handlingar, 51, 3-16. (in Swedish)

Hill, D. J., and Coauthors, 2014: Evaluating the dominant components of warming in Pliocene climate simulations. Climate of the Past, 10(1), 79-90.

Honda, M., J. Inoue, and S. Yamane, 2009: Influence of low Arctic sea ice minima on anomalously cold Eurasian winters. Geophys. Res. Lett., 36, L08707, doi: 10.1029/2008GL037079.

Honda, M., K. Yamazaki, Y. Tachibana, and K. Takeuchi, 1996: Influence of Okhotsk sea-ice extent on atmospheric circulation. Geophys. Res. Lett., 23(4), 3595-3598.

Honda, M., K. Yamazaki, H. Nakamura, and K. Takeuchi, 1999: Dynamic and thermodynamic characteristics of atmospheric response to anomalous sea-ice extent in the Sea of Okhotsk. J. Climate, 12, 3347-3358.

Hopsch, S., J. Cohen, and K. Dethloff, 2012: Analysis of a link between fall Arctic sea-ice concentration and atmospheric patterns in the following winter. Tellus, 64A, 18624, doi: 10.3402/tellusa.v64i0.18624.

Hurrell, J. W., 1995: Decadal trends in the North Atlantic Oscillation: regional temperatures and precipitation. Science, 269(5224), 676-679.

Inoue, J., E. H. Masatake, and T. Koutarou, 2012: The role of Barents Sea ice in the wintertime cyclone track and emergence of a warm-Arctic cold-Siberian anomaly. J. Climate, 25, 25612568 .

Intergovernmental Panel on Climate Change (IPCC), 2013: The Physical Science Basis. Contribution of working group I to the fifth assessment report of the intergovernmental panel on climate change. T. F. Stocker et al., Eds., Cambridge University Press, Cambridge, UK and New York, NY, USA, 1552 pp.

Jackson, J. M., E. C. Carmack, F. A. McLaughlin, S. E. Allen, and R. G. Ingram, 2010: Identification, characterization, and change of the near-surface temperature maximum in the Canada Basin, 1993-2008. J. Geophys. Res.: Oceans (19782012), 115, doi: 10.1029/2009JC005265.

Jaiser, R., K. Dethloff, D. Handorf, A. Rinke, and J. Cohen, 2012: Impact of sea-ice cover changes on the northern hemisphere atmospheric winter circulation. Tellus, 64A, 11595, doi: 10.3402/tellusa.v64i0.11595.

Jaiser, R., K. Dethloff, and D. Handorf, 2013: Stratospheric response to Arctic sea ice retreat and associated planetary wave propagation changes. Tellus, 65A, 19375, doi: 10.3402/tellusa.v65i0.19375.

Johannessen, O. M., 2008: Decreasing Arctic Sea Ice mirrors increasing $\mathrm{CO}_{2}$ on decadal time scale. Atmos. Oceanic Sci. Lett., 1(1), 51-56.

Johannessen, O. M., and M. M. Bjørgo E, 1995: The Arctic's shrinking sea ice. Nature, 376, 126-127.

Johannessen, O. M., and Coauthors, 2004: Arctic climate change-observed and modelled temperature and sea ice variability. Tellus, 56A, 328-341.

Jungclaus, J., H. Haak, M. Latif, and U. Mikolajewicz, 2005: Arctic-North Atlantic interactions and multidecadal variability of the meridional overturning circulation. J. Climate, 18, 4013-4031.

Kim, B. M., S. W. Son, S. K. Min, J. H. Jeong, S. J. Kim, X. D. Zhang, T. Shim and J. H. Yoon, 2014: Weakening of the stratospheric polar vortex by Arctic sea-ice loss. Nature Communications, doi: 10.1038/ncomms5646.

Kinnard, C., C. M. Zdanowicz, D. A. Fisher, E. Isaksson, A. Vernad, and L. G. Thompson, 2011: Reconstructed changes in Arctic sea ice over the past 1450 years. Nature, 479, 509-512.

Koenigk, T, U. Mikolajewicz, J. Jungclaus, and A. Kroll, 2009: Sea ice in the Barents Sea: Seasonal to interannual variability and climate feedbacks in a global coupled model. Climate Dyn., 32, 1119-1138, doi: 10.1007/s00382-008-0450-2.

Kumar, A., and Coauthors, 2010: Contribution of sea ice loss to Arctic amplification. Geophys. Res. Lett., 37, L21701, doi: 10.1029/2010GL045022.

Langehaug, H., F. Geyer, L. Smedsrud, and Y. Q. Gao, 2013: Arctic sea ice decline and ice export in the CMIP5 historical simulations. Ocean Modeling, 71, 114-126, doi: 10.1016/ j.ocemod.2012.12.006.

Lehner, F., B. Andreas, C. R. Christoph, and F. S. Thomas, 2013: Amplified inception of European little ice age by sea iceocean-atmosphere feedbacks. J. Climate, 26, 7586-7602.

L'Heureux, M. L., A. Kumar, G. D. Bell, M. S. Halpert, and R. W. Higgins, 2008: Role of the Pacific-North American (PNA) pattern in the 2007 Arctic sea ice decline. Geophys. Res. Lett., 35, doi: 10.1029/2008GL035205.

Li, F., and H. J. Wang, 2012: Autumn sea ice cover, winter northern hemisphere annular mode, and winter precipitation in Eurasia. J. Climate, 26(11), 3968-3981.

Li, F., and H. J. Wang, 2013a: Spring surface cooling trend along the East Asian coast after the late 1990s. Chinese Sci. Bull., 58(31), 3847-3851.

Li, F., and H. J. Wang, 2013b: Relationship between Bering sea ice cover and East Asian winter monsoon Year-to-Year Variations. Adv. Atmos. Sci., 30(1), 48-56.

Li, F., and H. J. Wang, 2014: Autumn Eurasian snow depth, autumn Arctic sea ice cover and East Asian winter monsoon. Int. J. Climatol., doi: 10.1002/joc.3936 s.

Li, F., H. J. Wang, and Y. Q. Gao, 2014: On the strengthened relationship between East Asian winter monsoon and Arctic Oscillation: A comparison of 1950-1970 and 1983-2012. J. Climate, 27, 5075-5091, doi: 10.1175/JCLI-D-13-00335.1.

Liu, J. P., Z. H. Zhang, R. M. Horton, C. Y. Wang, and X. B. Ren, 2007: Variability of North Pacific Sea Ice and East AsiaNorth Pacific Winter Climate. J. Climate, 20, 1991-2001, doi: 10.1175/JCLI4105.1

Liu, J. P., J. A. Curry, H. J. Wang, M. Song, and R. M. Horton, 2012: Impact of declining Arctic sea ice on winter snowfall. Proc. Natl. Acad. Sci. U.S.A., 109, 4074-4079.

Liu, J. P., M. Song, R.M. Horton, and Y. Hu, 2013: Reducing spread in climate model projections of a September ice-free Arctic. Proc. Natl. Acad. Sci. USA, 110(31), 12571-12576, doi: 10.1073/pnas.1219716110.

Ma, J. H., H. J. Wang, and Y. Zhang, 2012: Will boreal winter precipitation over China increase in the future? An AGCM simulation under summer "ice-free Arctic" conditions. Chinese Sci. Bull., 57(8), 921-926.

Magnusdottir, G., C. Deser, and R. Saravanan, 2004: The effects of North Atlantic SST and sea ice anomalies on the winter circulation in CCM3. Part I: Main features and storm track characteristic of the response. J. Climate, 17, 857-876.

Mahajan, S., R. Zhang, and T. L. Delworth, 2011: Impact of the Atlantic Meridional Overturning Circulation (AMOC) on Arctic surface air temperature and sea ice variability. J. Climate, 24, 6573-6581. 
Matsumura, S., X. Zhang, and K. Yamazaki, 2014: Summer Arctic atmospheric circulation response to spring Eurasian snow cover and its possible linkage to accelerated sea ice decrease. J. Climate, 27, 6551-6558.

Mesquita, M. D. S., K. I. Hodges, D. E. Atkinson, and J. Bader, 2011: Sea-ice anomalies in the Sea of Okhotsk and the relationship with storm tracks in the Northern Hemisphere during winter. Tellus, 63(2), 312-323.

Miles, M. W., D. V. Divine, T. Furevik, E. Jansen, M. Moros, and A. E. J. Ogilvie, 2014: A signal of persistent Atlantic multidecadal variability in Arctic sea ice. Geophys. Res. Lett., 41(2), 463-469, doi: 10.1002/2013GL058084.

Miller, G. H., and Coauthors., 2012: Abrupt onset of the Little Ice Age triggered by volcanism and sustained by seaice/ocean feedbacks. Geophys. Res. Lett., 39, L02708, doi: 10.1029/2011GL050168.

Newson, R. L., 1973: Response of a general circulation model of the atmosphere to removal of the Arctic ice-cap. Nature, 241, 39-40.

Orsolini, Y., R. Senan, R. Benestad, and A. Melsom, 2012: Autumn atmospheric response to the 2007 low Arctic sea-ice extent in coupled ocean-atmosphere hindcasts. Climate Dyn., 38, 2437-2448.

Overland, J. E., and M. Wang, 2010: Large-scale atmospheric circulation changes are associated with the recent loss of Arctic sea-ice. Tellus, 62A, 1-9.

Overland, J. E., and M. Wang, 2013: When will the summer Arctic be nearly sea ice free? Geophys. Res. Lett., 40, 2097-2101, doi: $10.1002 / g r l .50316$.

Overland, J. E., J. A. Francis, E. Hanna, and M. Wang, 2012: The recent shift in early summer Arctic atmospheric circulation. Geophys. Res. Lett., 39, L19804, doi: 10.1029/2012GL 053268.

Peings, Y., and G. Magnusdottir, 2014: Response of the wintertime northern hemisphere atmospheric circulation to current and projected arctic sea ice decline: A numerical study with CAM5. J. Climate, 27, 244-264.

Petoukhov, V., and V. A. Semenov, 2010: A link between reduced Barents-Kara sea ice and cold winter extremes over northern continents. J. Geophys. Res., 115, D21111, doi: 10.1029/ 2009JD013568.

Polyak, L., and Coauthors., 2010: History of sea ice in the Arctic. Quat. Sci. Rev., 29(15), 1757-1778.

Porter, D. F., J. J. Cassano, and M. C. Serreze, 2012: Local and large-scale atmospheric responses to reduced Arctic sea-ice and ocean warming in the WRF model. J. Geophys. Res., 117, D11115, doi: 10.1029/2011JD016969.

Rinke, A., W. Maslowski, K. Dethloff, and J. Clement, 2006: Influence of sea ice on the atmosphere: A study with an Arctic atmospheric regional climate model. J. Geophys. Res.: Atmos. (1984-2012), 111, doi: 10.1029/2005JD006957.

Salzmann, U., and Coauthors, 2013: Challenges in quantifying Pliocene terrestrial warming revealed by data-model discord. Nature Climate Change, 3, 969-974.

Sand $\varnothing$, A. B., Y. Q. Gao, and H. R. Langehaug, 2014: Poleward ocean heat transports, sea ice processes and Arctic sea ice variability in NorESM1-M simulations. J. Geophys. Res.Ocean, 19(3), 2095-2108.

Schell, I. I., 1956: Interrelations of Arctic ice with the atmosphere and the ocean in the North Atlantic-Arctic and adjacent areas. J. Meteor., 13, 46-58.

Schell, I. I., 1970: Arctic ice and sea temperature anomalies in the northeastern north Atlantic and their significance for seasonal foreshadowing locally and to the eastward. Mon. Wea. Rev., 98, 833-850.

Screen, J. A., 2013: Influence of Arctic sea ice on European summer precipitation. Environ. Res. Lett., 8, 044015, doi: 10.1088/1748-9326/8/4/044015.

Screen, J. A., and I. Simmonds, 2010: The central role of diminishing sea ice in recent Arctic temperature amplification. Nature, 464, 1334-1337.

Screen, J. A., and I. Simmonds, 2012: Declining summer snowfall in the Arctic: Causes, impacts and feedbacks. Climate Dyn., 38, 2243-2256.

Screen, J. A., and I. Simmonds, 2013: Exploring links between Arctic amplification and mid-latitude weather. Geophys. Res. Lett., 40(5), 959-964.

Screen, J. A., I. Simmonds, C. Deser, and R. Tomas, 2013: The atmospheric response to three decades of observed Arctic seaice loss. J. Climate, 26, 1230-1248.

Screen, J. A., C. Deser, I. Simmonds, and R. Tomas, 2014: Atmospheric impacts of Arctic sea-ice loss, 1979-2009: Separating forced change from atmospheric internal variability. Climate Dyn., 43, 333-344, doi: 10.1007/s00382-013-1830-9.

Seierstad, I. A., and J. Bader, 2009: Impact of a projected future Arctic Sea Ice reduction on extratropical storminess and the NAO. Climate Dyn., 33, 937-943.

Semenov, V., I. I. Mokhov, and M. Latif, 2012: Influence of the ocean surface temperature and sea ice concentration on regional climate changes in Eurasia in recent decades. Izvestiya, Atmos. Oceanic Phys., 48(4), 355-372.

Semmler, T., D. Jacob, K. H. Schlünzen, and R. Podzun, 2004: Influence of sea ice treatment in a regional climate model on boundary layer values in the Fram Strait region. Mon. Wea. Rev., 132(4), 985-999.

Simmonds, I., and K. Keay, 2009: Extraordinary September Arctic sea ice reductions and their relationships with storm behavior over 1979-2008. Geophys. Res. Lett., 36, L19715, doi: 10.1029/2009GL039810.

Singarayer J. S., J. L. Bamber, and P. J. Valdes, 2006: Twenty-firstcentury climate impacts from a declining Arctic sea ice cover. J. Climate, 19, 1109-1125.

Stein, R., K. Fahl, and J. Müller, 2012: Proxy reconstruction of Arctic Ocean sea ice history-From IRD to IP25. Polarforschung, 82, 37-71.

Strey, S. T., W. L. Chapma, and J. E. Walsh, 2010: The 2007 seaice minimum: Impacts on the Northern Hemisphere atmosphere in late autumn and early winter. J. Geophys. Res., 115, D23103, doi: 10.1029/2009JD013294.

Stroeve, J., and Coauthors, 2008: Arctic sea ice extent plummets in 2007. Eos, Transactions American Geophysical Union, 89, $13-14$.

Stroeve, J. C., J. Maslanik, M. C. Serreze, I. Rigor, W. Meier, and C. Fowler, 2011b: Sea ice response to an extreme negative phase of the Arctic Oscillation during winter 2009/2010. Geophys. Res. Lett., 38, doi: 10.1029/2010GL045662.

Stroeve, J. C., M. C. Serreze, A. Barrett, and D. N. Kindig, 2011a: Attribution of recent changes in autumn cyclone associated precipitation in the Arctic. Tellus, 63A, 653-663.

Stroeve, J. C., M. C. Serreze, J. E. Kay, M. M. Holland, W. N. Meier, and A. P. Barrett, 2012a: The Arctic's rapidly shrinking sea ice cover: A research synthesis. Climatic Change, 110, 1005-1027, doi: 10.1007/s10584-011-0101-1.

Stroeve, J. C., V. Kattsov, A. Barrett, M. Serreze, T. Pavlova, M. 
Holland, and W. N. Meier, 2012b: Trends in Arctic sea ice extent from CMIP5, CMIP3 and observations. Geophys. Res. Lett., 39, L16502, doi: 10.1029/2012GL052676.

Strong, C., G. Magnusdottir, and H. Stern, 2009: Observed feedback between winter sea ice and the North Atlantic Oscillation. J. Climate, 22, 6021-6032.

Sun, J. Q., and H. J. Wang, 2012: Changes of the connection between the summer North Atlantic Oscillation and the East Asian summer rainfall. J. Geophys. Res., 117(D08110), doi: 10.1029/2012JD017482.

Sun, J. Q., H. J. Wang, and W. Yuan, 2009: Role of the tropical Atlantic sea surface temperature in the decadal change of the summer North Atlantic Oscillation. J. Geophys. Res., 114(D2027), doi: 10.1029/2009JD012395.

Tang, Q. H., X. J. Zhang, X. H. Yang, and J. A. Francis, 2013a: Cold winter extremes in northern continents linked to Arctic sea ice loss. Environ. Res. Lett., 8, 014036, doi: 10.1088/ 1748-9326/8/1/014036.

Tang, Q. H., X. J. Zhang, and J. A. Francis, 2013b: Extreme summer weather in northern mid-latitudes linked to a vanishing cryosphere. Nature Climate Change, 4, 45-60, doi: 10.1038/ NCLIMATE2065.

Tao, S. Y., 1959: Studies on cold spells in East Asia from 1949 to 1959. Acta Meteorologica Sinica, 30(3), 226-230 (in Chinese).

Vavrus, S. J., 1999: The response of the coupled Arctic sea iceAtmosphere system to orbital forcing and ice motion at $6 \mathrm{kyr}$ and 115 kyr BP. J. Climate, 12, 873-896.

Vihma, T., 2014: Effects of Arctic Sea ice decline on weather and climate: A review. Surveys in Geophysics, 35, 1175-1214, doi: 10.1007/s10712-014-9284-0.

Wang, H. J., and S. P. He, 2012: Weakening relationship between East Asian winter monsoon and ENSO after mid-1970s. Chinese Sci. Bull., 57(27), 3535-3540.

Wang, H. J., and S. P He, 2013: The increase of snowfall in Northeast China after the mid-1980s. Chinese Sci. Bull., 58(12), 1350-1354.

Wang, H. J., S. P. He, and J. P. Liu, 2013: Present and future relationship between the East Asian winter monsoon and ENSO: Results of CMIP5. J. Geophys. Res., 118, 5222-5237, doi: $10.1002 /$ jgrc. 20332.

Woodgate, R. A., T. Weingartner, and R. Lindsay, 2010: The 2007 Bering Strait oceanic heat flux and anomalous Arctic sea-ice retreat. Geophys. Res. Lett., 37, doi: 10.1029/2009GL041621.

Wu, B. Y., R. H. Huang, and D. Y. Gao, 1999: Effects of variation of winter sea-ice area in Kara and Barents Seas on East Asian winter monsoon. Acta Meteorologica Sinica, 13, 141-153.

Wu, B. Y., J. Z. Su, and R. H. Zhang, 2011: Effects of autumn- winter Arctic sea ice on winter Siberian high. Chin. Sci. Bull., 30, 3220-3228, doi: 10.1007/s11434-011-4696-4.

Wu, B. Y., R. H. Zhang, B. Wang, and R. D'Arrigo, 2009: On the association between spring Arctic sea ice concentration and Chinese summer rainfall. Geophys. Res. Lett., 36, L09501, doi: 10.1029/2009GL037299.

Wu, B., R. Zhang, R. D'Arrigo, and Z. Su, 2013b: On the Relationship between Winter Sea Ice and Summer Atmospheric Circulation over Eurasia. J. Climate, 26, 5523-5536.

Wu, B. Y., D. R. Handorf, K. Dethloff, A. Rinke, and A. X. Hu, 2013a: Winter Weather Patterns over Northern Eurasia and Arctic Sea Ice Loss. Mon. Wea. Rev., 141, 3786-3800, doi: 10.1175/MWR-D-13-00046.1

Wu, Q. G., and X. D. Zhang, 2010: Observed forcing-feedback processes between northern hemisphere atmospheric circulation and Arctic sea-ice coverage. J. Geophys. Res., 115, D14199, doi: 10.1029/2009JD013574.

Wyatt, M. G., and J. A. Curry, 2014: Role for Eurasian Arctic shelf sea ice in a secularly varying hemispheric climate signal during the 20th century. Climate Dyn., 42, 2763-2782.

Yamamoto, K., Y. Tachibana, M. Honda, and J. Ukita, 2006: Intraseasonal relationship between the Northern Hemisphere sea ice variability and the North Atlantic Oscillation. Geophys. Res. Lett., 33(14), L14711, doi: 10.1029/2006GL026286.

Yan, Q., Z. Zhang, H. Wang, and R. Zhang, 2014: Simulation of Greenland ice sheet during the mid-Pliocene warm period. Chinese Sci. Bull., 59(2), 201-211.

Yang, S., and J. H. Christensen, 2012: Arctic sea ice reduction and European cold winters in CMIP5 climate change experiments. Geophys. Res. Lett., 39, L20707, doi: 10.1029/2012 GL053338.

Yang, X. Q., Q. Xie, and S. S. Huang, 1994: Numerical simulation in the impact of Arctic sea ice anomaly on the East Asian summer monsoon. Acta Oceanologica Sincia, 16(5), 34-40 (in Chinese).

Zhang, J. T., D. Rothrock, and M. Steele, 2000: Recent changes in Arctic sea ice: The interplay between ice dynamics and thermodynamics. J. Climate, 13, 3099-3314.

Zhao, P., X. D. Zhang, X. J. Zhou, M. Ikeda, and Y. H. Yin, 2004: The sea ice extent anomaly in the North Pacific and its Impact on the East Asian summer monsoon rainfall. J. Climate, 17, 3434-3447.

Zhou, M. Z., and H. J. Wang, 2014: Late Winter Sea Ice in the Bering Sea: Predictor for Maize and Rice Production in Northeast China. J. Appl. Meteor. Climatol., 53, 1183-1192.

Zhou, M. Z., H. J. Wang, S. Yang, and K. Fan, 2013: Influence of springtime North Atlantic Oscillation on crops yields in Northeast China. Climate Dyn., 41(11-12), 3317-3324. 